\title{
Genetic and biochemical changes of the serotonergic system in migraine pathobiology
}

\author{
Claudia Francesca Gasparini ${ }^{1}$, Robert Anthony Smith ${ }^{2}$ and Lyn Robyn Griffiths ${ }^{2 *}$
}

\begin{abstract}
Migraine is a brain disorder characterized by a piercing headache which affects one side of the head, located mainly at the temples and in the area around the eye. Migraine imparts substantial suffering to the family in addition to the sufferer, particularly as it affects three times more women than men and is most prevalent between the ages of 25 and 45 , the years of child rearing. Migraine typically occurs in individuals with a genetic predisposition and is aggravated by specific environmental triggers. Attempts to study the biochemistry of migraine began as early as the 1960s and were primarily directed at serotonin metabolism after an increase of 5-hydroxyindoleacetic acid (5-HIAA), the main metabolite of serotonin was observed in urine of migraineurs. Genetic and biochemical studies have primarily focused on the neurotransmitter serotonin, considering receptor binding, transport and synthesis of serotonin and have investigated serotonergic mediators including enzymes, receptors as well as intermediary metabolites. These studies have been mainly assayed in blood, CSF and urine as the most accessible fluids. More recently PET imaging technology integrated with a metabolomics and a systems biology platform are being applied to study serotonergic biology. The general trend observed is that migraine patients have alterations of neurotransmitter metabolism detected in biological fluids with different biochemistry from controls, however the interpretation of the biological significance of these peripheral changes is unresolved. In this review we present the biology of the serotonergic system and metabolic routes for serotonin and discuss results of biochemical studies with regard to alterations in serotonin in brain, cerebrospinal fluid, saliva, platelets, plasma and urine of migraine patients.
\end{abstract}

Keywords: Migraine with aura, Migraine without aura, Cortical spreading depression, Serotonin, Metabolomics, Melatonin, Tryptophan, Triptans, SERT, Kyneurine pathway

\section{Review} Introduction

Migraine is a painful neurological disease whose manifestation results from an interplay of enviro-genomic factors and the severity of symptoms often propels sufferers to abuse medication. Migraine reigns as the $8^{\text {th }}$ most burdensome disease in the world and the $4^{\text {th }}$ most in women according to the 2012 Global Burden of Disease study [1]. The clinical features of migraine according to IHS classification include intense, pulsating head pain localized to one side of the head that can effectively

\footnotetext{
* Correspondence: lyn.griffiths@qut.edu.au

${ }^{2}$ Genomics Research Centre, Institute of Health and Biomedical Innovation, School of Biomedical Sciences, Queensland University of Technology, Musk Ave, Kelvin Grove, QLD 4059, Australia

Full list of author information is available at the end of the article
}

disable its sufferer for up to $72 \mathrm{~h}$ [2]. Accompanying symptoms of migraine in addition to the headache include nausea, vomiting, and hypersensitivity to lights, sounds and/or smells, all of which can be aggravated by physical activity [2]. The disease is believed to develop in genetically vulnerable populations, disabling an estimated $12 \%$ of Caucasian people, varying in accordance with genetic background, climatic region, socioeconomic status, life-style, presence of other diseases and the general health of the sourced population [3, 4]. There is also a well-established overrepresentation of the disease in females, affecting $\sim 3$ times more females than males due to a complex interplay of hormonal and enviro-genomic exposures [5].

Migraine is diagnosed by specialized physicians utilizing the current International Headache Society (IHS) 
criteria (ICHD-3, beta version currently available at https://www.ichd-3.org/) [2]. Acceptance of these criteria has facilitated modern day molecular genetic research by standardising diagnosis of headache and headache-related disorders in absence of any clearly identifiable pathology, biomarkers and diagnostic tests. Migraine is classified into two main types, distinguished by the presence of a variety of sensory disturbances (termed aura) that can occur in the early stages of the headache: migraine with aura (MA) or migraine without aura (MO) [2]. Migraine is a complex disorder that evolves due to a combination of multiple genes and external factors such as gene-environment, genenutrient, gene-gene interactions and epigenetics that result in multiple presentations of the disorder making it difficult to pinpoint the relevant genomic risk factors [6].

Literature on the pathophysiology of migraine continues to evoke a disorder of neurovascular origin as demonstrated by the involvement of cranial neurovascular anatomical structures. This neurovascular scaffold encompasses three main domains: a neural domain (i.e., hyperexcitability and CSD-like neural events) [7, 8], vascular domain (intracranial constriction and vasodilation) and a nociceptive domain (activation of trigeminal structures, a network of neurons that sense pain signals and release of several 'migraine mediators', neuropeptides, such as CGRP). These three domains describe the main aspects of the current model of the pathobiology of migraine [9-11]. Genetic studies have focused on investigating genetic variability in multiple neurotransmitter systems which interact and overlap at different levels.

Neurotransmitters regulate intracellular signal transduction events as well as neural function, morphology and circuit formation [12]. Interruptions in intra- and interneuronal signalling due to inappropriate activation or inactivation of regulatory proteins, including nuclear transcription factors can alter the electrophysiological signalling of neurons resulting in structural and functional changes [13-15]. This hypothesis of 'malfunctioning ion channels' that set the electrical activity in nerve cells that form circuits modulating pain was revived by the discovery of mutations in the potassium channel TRESK [15]. Similarly, the recognition that the three main types of Familial Hemiplegic Migraine are caused by mutations in ion channels implies that ion channel dysfunction may be the primary cause for migraine symptoms in non-familial cases as well [16]. In this review we considered the biology of the serotonergic system and its metabolism and results of biochemical studies regarding the content of serotonin in the brain, cerebrospinal fluid (CSF), saliva, platelets, plasma and urine of migraine patients and we link the evidence together in a biochemical model that considers the application of metabolomics for guiding future research on the pathobiology of migraine.

\section{Serotonergic biology and genetics}

Biochemical, genetic and pharmacological studies have investigated potential dysfunction of neurotransmitters in migraine susceptibility. The involvement of serotonin in migraine has been known for many years following Sicuteri's observations of an increase of 5-hydroxyindoleacetic acid (5-HIAA), the main metabolite of serotonin, in the urine of 15 patients during migraine attacks [17]. This was the first indication of an anomaly of serotonin metabolism in migraineurs and since then, many scientific research studies have focused on the genetic components of the serotonergic system (see Table 1). Receptors, transporters and enzymes are the key molecular mediators that regulate and maintain serotonin levels in the brain and periphery. Serotonin is distributed in neuronal and several non-neuronal tissues of the cardiovascular system, gastrointestinal, renal systems and the blood [18]. Serotonin regulates a wide array of physiological functions via a specific set of receptors which are mostly G protein-coupled receptors (except receptor 5HT3 which is a ligand gated cation channel) that activate an intracellular second messenger cascade to mediate excitatory or inhibitory neurotransmission [19]. Serotonin receptors have been localized in vestibular and trigeminal ganglion cells in monkey [20].

Current research on the biology of the serotonergic system in disease is focusing on genetic alterations in synaptic and post-receptor signalling proteins that affect serotonergic neurotransmission by increasing or decreasing serotonin's actual or effective availability in the CNS (See Table 1) [21]. Genetic variability at the level of gene transcription, mRNA processing and translation or posttranslational modification as well as intracellular trafficking in the genetic components of the serotonergic system may generate gene products that may lead to structural and functional changes in brain circuits and provoke disease [22]. The two most studied components of the serotonergic system that have come into the spotlight in determining susceptibility to migraine as well as multiple neuropsychiatric disorders are the serotonin transporter (SERT, also known as SLC6A4), which reuptakes serotonin from the synapse, and monoamine oxidase A (MAOA), an important enzyme that degrades serotonin and metabolizes triptans [23]. Both these proteins are important in regulating levels of serotonin in the brain and carry polymorphisms in their promoter regions that cause differential transcriptional activity and thus impact drug metabolism [22, 24-26].

Several association studies have investigated genetic variants that may alter the functions of genes involved in serotonin functionality and regulation. The serotonin transporter gene SERT has been extensively studied. In this gene, two polymorphisms have been of particular interest. The first polymorphism consists of a $17 \mathrm{bp}$ variable number of tandem repeats known as (STin2 VNTR) 


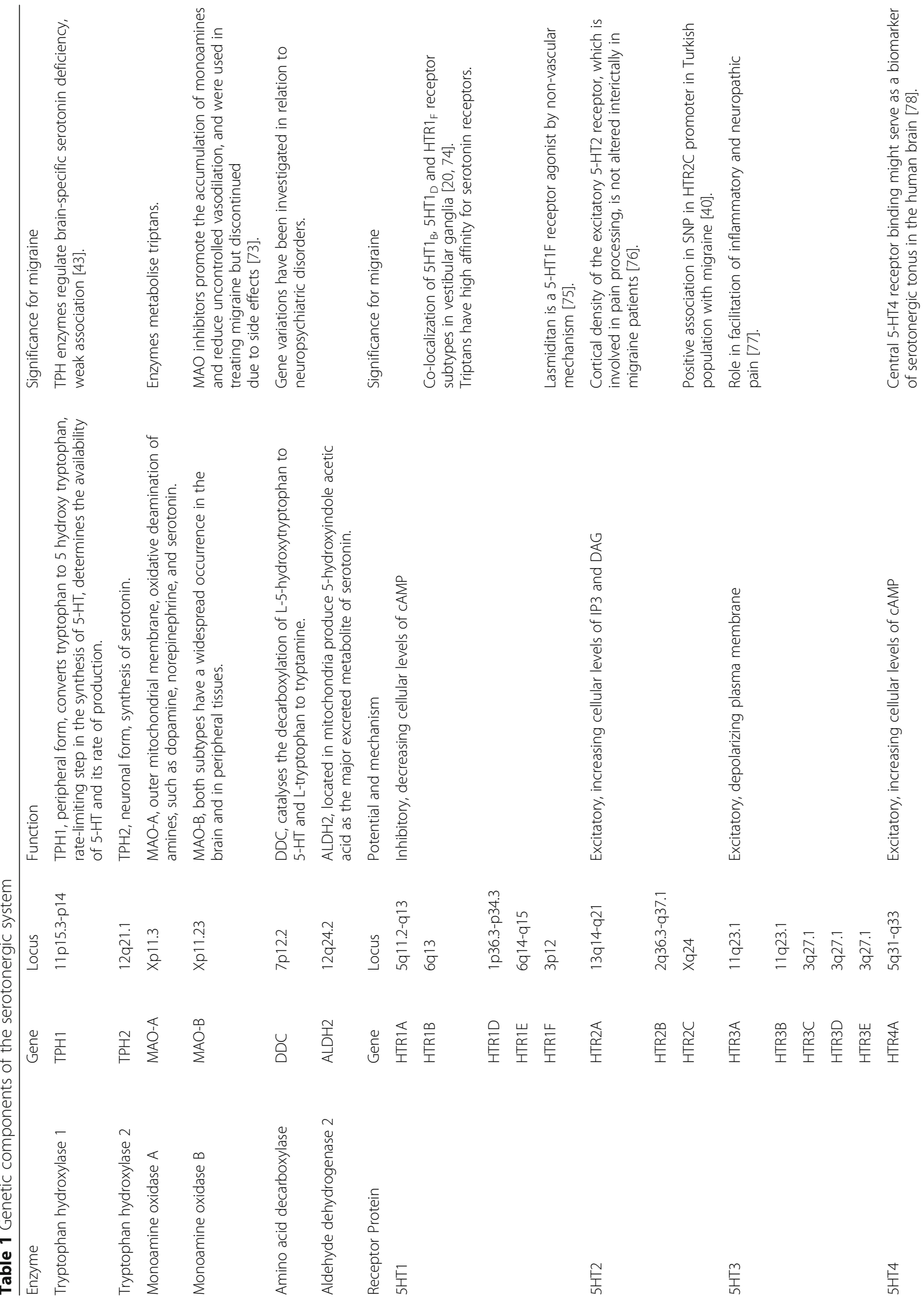




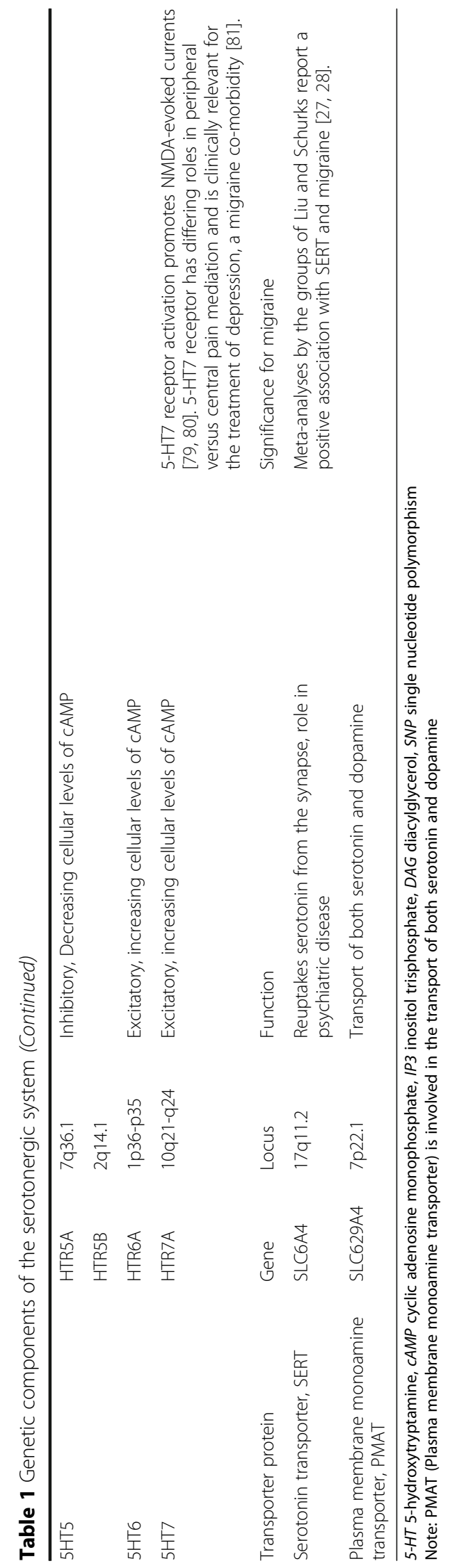


in intron 2 with two common alleles (STin2.10 and STin2.12) composed of 10 or 12 repeat units respectively [27]. To get a clearer picture, Schurks et al., [27] considered five studies that evaluated the 5-HTT VNTR STin2 polymorphism and concluded the STin2 12/12 genotype may be influential in determining migraine susceptibility among populations of European descent. A further metaanalysis by Liu et al., [28] reviewed 15 studies and found that the 5-HTT VNTR STin2 12/12 genotype confers an increased risk for migraine in the general population.

The second polymorphism is a 44-bp insertion/deletion functional polymorphism in the promoter region known as 5-HTTLPR. There are two common allelic forms, and the 14 repeat containing short variant $(\mathrm{S})$ is associated with slower clearing of serotonin from the synaptic cleft [29]. Analysis of this polymorphism has provided conflicting results. The $S$ allele has shown association with migraine in some studies [30-33] while in other studies no evidence of association was identified [34, 35]. In a meta-analysis of 10 studies of Europeans and Asians Schurks et al., reported no overall association between the 5-HTTLPR polymorphism and migraine, although gender and migraine aura status may influence results among Europeans [29]. Although various polymorphisms in serotonin related genes have showed altered allelic distribution in different migraine populations there has been, to date, insufficient evidence to confirm a specific serotonin receptor gene being directly associated with the disorder [36, 37].

Genetic studies continue to provide new data regarding the involvement of serotonin in migraine and in particular support the idea that migraine is a polygenic disorder as recently reported in a large meta-analysis of 375,000 individuals by Gormley et al., [38] that identified 38 susceptibility loci for migraine. Thompson et al. identified a positive association at the 5-HT1D receptor locus in 64 extended families with migraine with aura [39]. The locus $1 \mathrm{p} 36$ for the $5-H T 1 D$ gene is a candidate locus because it is a target of triptan drugs and it was also considered in the context of the association of PRDM16 in MO which is located proximally to $1 \mathrm{p} 36$. Recently, a significant association was identified between migraine and a functional polymorphism rs3813929 localised in the promoter region of the serotonin receptor gene 5-HT2C [40]. The T allele of this polymorphism affects the transcription rate of the 5-HT2C receptor and was more common in a Turkish population with migraine [41].

Additionally, genetic research has explored serotonin synthesis and its role in migraine. Serotonin is synthesized in a short metabolic pathway consisting of two enzymes: tryptophan hydroxylase (TPH) and amino acid decarboxylase (DDC) (See Table 1) [42]. The TPH2 gene is an obvious candidate to genotype because in theory low activity of this enzyme may decrease the amount of serotonin available in the brain. However, a study by
Jung et al., [43], did not find a positive association with migraine for two SNPs (rs1487275 and rs1386486) in the TPH2 gene (TPH1 is the peripheral form, TPH2 is the neuronal form) in a population of 503 migraineurs and 515 healthy controls [43]. Although this study does not support TPH2 as a key player in the migraine circuit $\mathrm{TPH} 2$ is emerging as a therapeutic target for stress disorders and abnormalities in TPH activity have been implicated in a variety of psychiatric disorders [44-46]. Conceivably, there may be other effects, including epigenetic, gene regulatory and or expression effects affecting this locus yet to be determined [44]. These data together with TPH2 knockout mice have provided additional insights into the role of TPH enzymes in regulating brain-specific serotonin deficiency [47-49].

\section{Migraine therapy and triptans}

Triptans are currently the most effective drugs in treating migraine and are the supporting pillar of migraine therapy [50]. Triptans amplify the serotonin signal by stimulating serotonin receptors located in cranial blood vessels and nerve endings and relieve pain by constricting blood vessels and inhibiting the release of peptides, including CGRP [51] and substance P as well as acting in other ways not yet known [52]. At the cellular level triptans alleviate migraine symptoms by binding to serotonin $5-\mathrm{HT} 1 \mathrm{~b}, \mathrm{~d}$ and $\mathrm{f}$ receptors along pain signaling circuits and are effective due to high receptor specificity and disease specificity [53]. Recent studies [54-56] continue to reveal triptans complex actions including metaanalyses comparing the effectiveness of triptans alone or in combination with other drugs [57]. Although triptans are the most effective drugs for migraine they exhibit therapeutic variability in different patient groups. The different levels of drug response can be explained by different metabolic routes, rates and efficiency.

In a meta-analysis by Cameron et al., 133 randomized controlled trials were included and the conclusion from this study was that triptans are generally better than ergots and provide equal or better pain relief when compared with non-steroidal anti-inflammatory drugs (NSAIDs), acetylsalicylic acid (ASA) and acetaminophen [57]. Triptans used in combination with ASA or acetaminophen, or by alternative administration methods (injectables) yielded slightly better outcomes than standard dose triptan tablets. Thorlund et al., evaluated the efficacy of seven triptans in a multiple treatment comparison meta-analysis by examining data from 74 double-blinded randomized clinical trials comparing triptans to either placebo or to another triptan [58]. Among the seven different triptans tested, eletriptan was the best triptan and all triptans were found better than placebo [58]. This result was also upheld by a recent 
report showing that triptans still have the most favorable efficacy-tolerability profile [59].

The hunt for better more specific drugs continues particularly in the era of pharmacogenetic research whose goal is to evaluate the impact of genetic constitution on migraine drug response [60]. Pharmacogenetics recognizes that numerous genes (drug metabolizing enzymes and drug transporters) play a role in the mechanism of drug response, resistance, toxicity, drug transport or drug targeting and ultimately affect how patients metabolize and consequently respond to different drug regimens $[61,62]$. This information can help inform doctors prescribing practices ie. responders versus nonresponders, avoiding adverse drug reactions, optimizing drug dose for the individual and ultimately guide prescription of the 'right' triptan to the 'right' patient [63].

In a study by Terazzino et al., the STin2 VNTR polymorphism in the SERT gene was shown to be associated with a higher risk of inconsistent response to triptans in migraine patients [64]. However the authors caution some limitations in their study such as a small sample size but nevertheless support future pharmacogenetic testing to identify algorithms for more effective treatment [64]. Recently, Christensen et al. identified a single risk variant, rs2651899 in the PRDM16 gene among 12 single nucleotide polymorphisms (SNPs) genotyped chosen based on prior GWAS findings by Antilla [65] to be significantly associated with efficacy of triptans [60]. To explore the role of genetic factors in drug metabolism Gentile et al., 2010 genotyped polymorphisms in CYP450 and MAOA, genes that are involved in Phase I metabolic reactions, and in target mechanisms (GNB3) of triptans and reported a significant correlation between MAOA uVNTR polymorphism and a chronic migrainous population [66, 67]. Serotonin receptors are also targeted by other drugs besides triptans and in a study by Brandl et al., polymorphisms in serotonergic genes (HTR2A, SERT) were found to be associated with antipsychotic treatment response [68].

In addition to pharmacogenomics a new paradigm has emerged 'pharmacometabolomics' for characterizing the metabolic (pharmacokinetic and pharmacodynamic) response to a drug taking into account both environmental and genomic factors [69]. Although there is still a paucity of studies in this domain, recent studies are using both metabolomic and genomic data to study selective serotonin reuptake inhibitor (SSRI) treatment outcomes in patients with major depressive disorder (MDD) by use of a "pharmacometabolomic-informed" pharmacogenomic research strategy [70]. In a follow up study in 2016, Gupta et al., uncovered two main SNP signals in two candidate genes (TSPAN5 and ERICH3) which were associated with the clinical response to SSRI therapy in MDD patients [71]. Functional genomic studies assessed serotonin pathway enzyme expression after knockdown (KD) or over-expression (OE) of TSPAN5 and ERICH3 in neurally-derived cell lines by qRT-PCR and quantitative Western blot. KD of TSPAN5 was associated with a significant decrease of mRNA and protein levels for the serotonin pathway enzymes TPH1, TPH2, DDC, MAOA, as well as the serotonin transporter SLC6A4. Both TSPAN5 and ERICH3 proteins affect serotonin concentrations in cell culture media. The identification of ERICH3 and TSPAN5 in the regulation of serotonin or variation in SSRI response is novel and recent studies have reported TSPAN5 may also promote Notch signalling [72].

Although specific SNPs in genes that metabolize triptans have yet to be identified, current pharmacogenetics studies indicate that defining the effect SNPs have on drug metabolism and treatment response may have value in classifying patients into groups of poor metabolizers to predict therapeutic responses and to evaluate sex differences. Several studies have shown that SNPs in genes of most metabolic enzymes can affect enzyme activities and may account for inter-individual variation, in drug bioavailability and efficacy and consequently can bear a role in therapy response [63]. Results of future testing the clinical utility of SNPs and genetic variability in the signalling components of the serotonergic system as well as additional genes involved in triptan metabolism will impact patient care and may be useful to personalize medicine.

\section{Metabolic routes of serotonin}

Tryptophan - Indole-kynurenine-niacin pathway Tryptophan is a requisite precursor necessary for various metabolic reactions primarily the synthesis of serotonin, proteins, melatonin, tryptamine and kynuramines [82, 83]. In the body, tryptophan is metabolized, via two basic pathways, the indole-kynurenine-niacin pathway and the serotonin-melatonin pathway [84]. The majority of tryptophan, $99 \%$ is metabolized and degraded along the kynurenine pathway which generates neuroactive compounds collectively called the kynurenines that antagonize the NMDA receptors [85]. Several studies of neurological diseases have reported kynurenine pathway (KP) metabolites and/or enzyme activity to be up- and/ or down-regulated in relation to disease [86, 87]. Recently Curto et al., identified an association of fluctuations of kynurenine metabolites in serum samples from 21 cluster headache patients [88]. Curto et al., also identified altered kynurenine pathway metabolites in serum of chronic migraine patients [89]. Indeed activation or inhibition of kynurenine pathway enzymes and accumulation of kynurenines within the CNS has been considered a therapeutic strategy [90]. However, the potential of this therapeutic strategy has not yet been tried in migraine [91]. 
To investigate central and peripheral serotonin turnover in neurological disorders and in depressed mood, researchers have adopted the tryptophan depletion technique (Acute Tryptophan Depletion ATD) [82]. Initial studies in healthy volunteers showed that depletion of tryptophan is correlated with a decline in central serotonin turnover $[92,93]$. The tryptophan-serotonin relationship has been confirmed in animal models [94-96] and was first demonstrated in 1970, indicating this mechanism may be potentially important in serotonin related pathologies in humans [97, 98]. Changes in the composition of the blood plasma in the periphery can influence functioning of the nervous system and affect various serotonin-dependent brain functions and mood states like depression [99-101]. Changes in diet and nutrition can lead to changes in brain levels of the precursors for neurotransmitter synthesis and influence the rates at which neurons synthesize neurotransmitters [101]. Tryptophan depletion increases nausea, headache and photophobia in migraine sufferers [102]. Two studies in the 70s, tested L-tryptophan treatment in headache patients and reported headache indices were markedly lower with supplementation of L-tryptophan than with placebo [103, 104]. The utility of tryptophan for both research and clinical purposes has been underexplored. Further analysis of the relationship of plasma tryptophan with brain serotonin metabolism in both normal and diseased states will be beneficial to understanding the complex serotonergic biochemistry of migraine.

Tryptophan - Serotonin-melatonin pathway Melatonin is a hormone that is synthesised at night-time from the precursor tryptophan in the pineal gland. Endogenous melatonin plays an important function in regulating circadian rhythms for proper sleep-wake cycles as well as many neuronal and hormonal functions [105, 106]. Multiple studies have demonstrated altered levels of melatonin secretion at night in the plasma or urine of migraine patients with cluster headache, migraine with and without aura, menstrual migraine, and chronic migraine relative to controls that spurred further investigation of melatonin as a prophylactic therapy [107-113]. Melatonin has also been found to be altered in other central nervous system (CNS) disorders, such as stroke, obsessive-compulsive disorder, mood and schizophrenia [114, 115]. Melatonin has regulatory effects on gastrointestinal tract motility and sensation, has sleep promoting effects and mood regulation and anti-stress effects [116]. Consequently, it is not surprising that melatonin supplements have shown potential in diminishing pain intensity in migraine comorbid conditions such as fibromyalgia and irritable bowel syndrome [116, 117].

Melatonin has been considered to hold therapeutic properties on headache profiles due to its normalizing effects on circadian rhythms and sleep and was further pursued in controlled trials because it is non-toxic, low cost and easily available over the counter in most countries (see Table 2) $[118,119]$. Bougea et al., [120] conducted the longest trial lasting for a period of 6 months and demonstrated a positive effect in a children patient group. Studies on melatonin use in migraine have had some limitations, such as lack of adequate control and placebo, had a small sample size and throughout some of the trials the patients were permitted to take rescue medication for symptomatic relief of migraine during the trial period, limiting the comparisons that can be made. The future of melatonin-based therapy may also include melatonin receptor agonists and the design of trials with a longer follow up period, standardized designs, controls and IHS guidelines to establish the utility of melatonin-based therapy as a prophylactic therapy [121].

Tryptophan and tryptamine Tryptamine is another functional neuromodulator produced from tryptophan metabolism and structurally related to serotonin $[126,127]$. D'Andrea et al., [115] identified low levels of tryptamine in the plasma of 73 chronic migraine $\mathrm{CM}$ patients and 13 chronic tension-type headache (CTTH) patients relative to a group of 37 healthy subjects [128]. In contrast the levels of circulating 5-HT and 5-HIAA were within normal range. The low tryptamine plasma levels found in CM and CTTH patients lead the authors to the conclusion that these two primary chronic headaches are characterized by "neurotransmitter and neuromodulator metabolic abnormalities in a hyperexcitable and hypoenergetic brain" due to insufficient serotonergic control of the pain threshold [129]. The role of tryptophan and tyrosine metabolism in migraine headache is reviewed in D’Andrea et al., [129-131].

\section{PET imaging studies of serotonin}

In the study of neurological disorders such as migraine, a recognizable limitation with investigating in vivo the biochemistry of CNS functioning is access to neuronal brain tissue of affected patients for controlled experimental study [132]. In view of the non-existence of high-quality post-mortem brain tissue samples to study CNS functioning in vivo, peripheral blood is being proposed as a valid surrogate for genetic studies of migraine [133], along with cerebrospinal fluid, saliva, platelets, plasma and urine to study neurotransmitter function. Given that migraine is a complex multi-faceted disorder, it makes sense to take a multi-dimensional approach that considers the whole organism.

The continued development and increasing availability of positron emission tomography (PET) and single positron emission computerized tomography (SPECT), and radio-ligands has enabled the study of serotonergic 


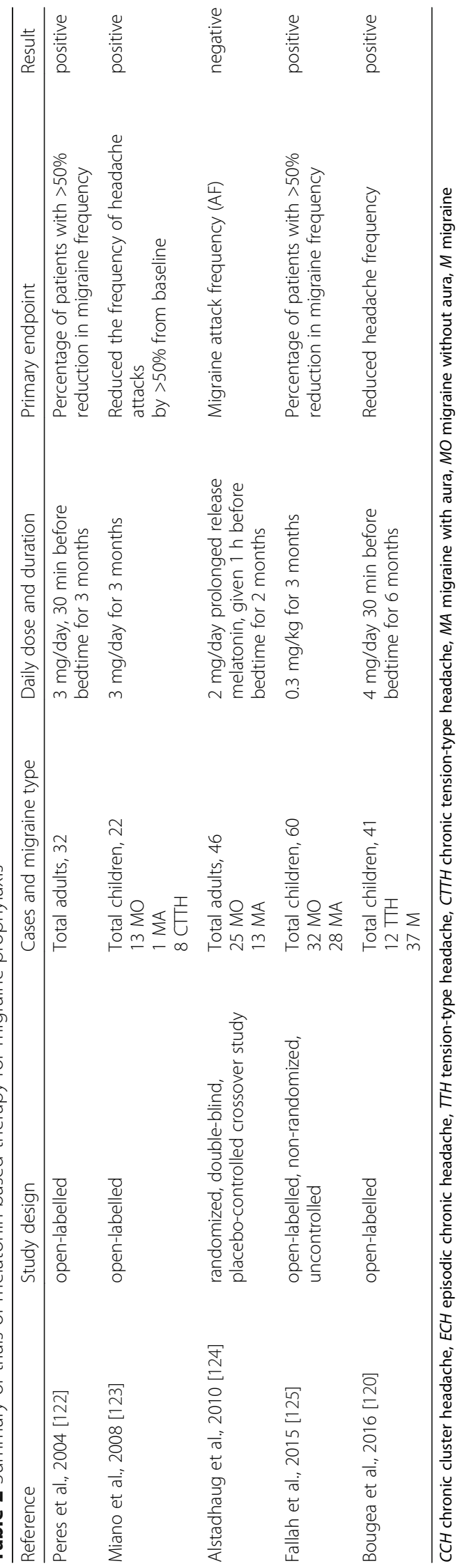


biology in vivo [134, 135]. Due to high sensitivity and better anatomic resolution, imaging techniques have provided an entry point to study perturbed functional networks in neurologic and psychiatric disorders [136] and obtain more information about the distribution, density and activity of single receptor molecules in relation to migraine-specific actions of triptans [137]. Three studies, have thus far employed the non-invasive method [138] PET imaging using the tracer $\alpha-\left[{ }^{11} \mathrm{C}\right]$ methyl-L tryptophan $\left({ }^{11} \mathrm{C}\right.$-AMT) for measuring serotonin synthesis in the human brain [139]. This method is based on the regional trapping of tracer ${ }^{11} \mathrm{C}$-AMT concentration and uses in vivo measurements of ${ }^{11} \mathrm{C}$-AMT plasma with reference to the brain trapping constant $\left(\mathrm{K}^{*}, \mathrm{~mL} / \mathrm{g} / \mathrm{mi}\right.$ nute) [138]. Using this method, Chugani et al., [127] reported a trend of elevated serotonin synthesis capacity in three female patients with $\mathrm{MO}$ after migraine patients were treated prophylactically with beta-adrenergic antagonists propranolol or nadolol, thought to be due to antagonism of the 5-HT1A receptor on serotonergic neurons [140]. Additionally, two other PET studies demonstrated that serotonin receptors/transporters can be upregulated interictally (in between attacks) in migraine [141, 142].

Sakai et al., performed a similar study in six migraine patients with PET imaging, scanning participants during an attack, after administering sumatriptan and in between attacks [143]. Statistically significant changes were reported only in the migraine group treated with sumatriptan. Serotonin synthesis was significantly reduced, with a $33 \%$ reduced uptake of ${ }^{11} \mathrm{C}$-AMT in a majority of brain regions, similar effects were also reported in rats $[143,144]$. The observed decrease in serotonin synthesis could be the body's physiological adaptation to the presence of triptan which mimics the effect of serotonin. In a recent study, Sakai et al. tested the hypothesis of serotonergic dysfunction in migraine by scanning six female migraine subjects with $\mathrm{MO}$ at baseline and after oral administration of $40 \mathrm{mg}$ of eletriptan, the triptan with the highest lipophilicity [145]. In the migraine group who received eletriptan, a significantly reduced (16.3\%) global $\mathrm{K}^{*}$ value for serotonin was obtained in the migraine subjects in the interictal phase of their condition [145]. Park et al., in a pilot study of eight female migraine patients investigated the availability of SERT in the brain stem and concluded that migraineurs who experience more painful headaches have lower serotonin neurotransmission and additionally reported an age-related decline of SERT availability [146]. In summary, the results from these studies suggest that brain serotonin synthesis rate may be altered in migraineurs and that triptans are effective on pain pathways by decreasing brain serotonin synthesis.

\section{Biochemical studies of serotonin in CSF and saliva}

The underlying hypothesis motivating studies of CSF is that because CSF is in direct contact with the brain interstitial fluid, serotonin and biochemical changes in the brains of migraine patients may best be reflected in this fluid [147]. Studies examining CSF are few, however, because they require spinal puncture, a costly and invasive procedure. Two studies, measuring serotonin activity in CSF can be found, one by Barrie et al., [135] which indicated no change in 5HIAA levels in CSF of migraine patients with respect to the controls and [148] one study by Kangasni et al., [149] reported an increase in 5HIAA levels in CSF (see Table 4).

Saliva has been used as a diagnostic tool to evaluate neurotransmitter function because it contains a variety of neuropeptides, integrating with the trigeminovascular and neuroendocrine systems [150-152]. There have been more studies trying to use saliva in the diagnostic and therapeutic assessment of migraine, e.g. the studies of Cady et al. [153] and Bellamy et al. [154] on CGRP in saliva of migraineurs. To date only one study by Marukawa et al., reported higher concentrations of serotonin and substance P in TTH patients [155]. The clinical usefulness of saliva has not yet been established, additional studies may be able to develop protocols able to make use of this easily accessible fluid, perhaps through correct timing of sampling [156].

\section{Biochemical studies of serotonin in platelets}

Interest in investigating platelets and peripheral biochemical factors is based on their interaction and proximity with the vascular endothelium. The vascular endothelium is a metabolically and physiologically active tissue that is semi-permeable and is important in regulating vascular tone [157]. Neurotransmitters and other vasoactive agents capable of modulating the nerve and vascular systems are actively produced by the vascular endothelium and can disrupt endothelial function [158]. Complex functional interactions that cause changes in endothelial function, vascular oxidative stress, promote platelet activation and enhance the inflammatory process can change the coagulant properties of blood producing alterations in neurovascular function and platelets may be an important part of these processes [159-162]. Attention has turned to the role of platelets in migraine due to the association and comorbidity of migraine with several cerebrovascular disorders, including arterial dissection, ischemic stroke, and cardiovascular disease as well as the increased risk of thromboembolic events and the favourable effects of antiplatelet medication $[163,164]$.

Platelets carry the largest reserve of serotonin which they capture from enterochromaffin cells [165]. In the gastrointestinal tract, serotonin acts as a key signalling molecule mediating many GI functions, including peristalsis, secretion, vasodilation and perception of pain or nausea, vomiting, which are common symptoms experienced by migraineurs [166-168]. Additionally, platelets 
express SERT proteins (membrane-bound serotoninselective reuptake transporter) that are identical to brain SERT [169]. Due to its role in clearing serotonin from the synaptic cleft, SERT plays a central role in neurotransmission and a broad role in brain activity making it a sought after therapeutic target of multiple neuropsychiatric disorders [170]. SERT knockout mice display notable reduction $(60-80 \%)$ in serotonin concentration in several brain regions [171] and markedly depleted serotonin tissue stores [172-174].

Numerous studies have found an association between migraine and a dysfunction in platelets (see Tables 3 and 4). The platelet changes that have been described in migraineurs include increased platelet-to-platelet aggregation and up-regulation of platelet-leukocyte aggregates. Morphological differences in platelets of migraineurs reported include: 1) containing more ADP; 2) having more dense granules and; 3) showing qualitative differences in their serotonin release reaction and clumping [175]. The contemporary literature is not conclusive on the relationship between platelet serotonin content and migraine however it generally agrees that the distorted behaviour of platelets presents with subtle changes in various functions (reviewed in [176]). In a case study of two sisters with hemiplegic migraine, low levels of systemic serotonin, including the CSF serotonin metabolite 5-hydroxyindoleacetic acid and low platelet serotonin levels were described [177]. Interestingly, administration of 5-hydroxytryptophan (a precursor of serotonin) and carbidopa ameliorated the sisters' clinical symptoms.

For the most part, investigations report increased platelet activation and it is argued that these changes could reflect parallel biochemical changes in the CNS (see Tables 3 and 4). Patterns of platelet behaviour/activation have also been found to differ in migraine subgroups, a finding that could indicate different pathomechanisms [178, 179]. There is, however, no platelet phenotype that can be used as a direct diagnostic biomarker for migraine [180]. It is difficult to draw final conclusions for platelet biology studies in migraine as they have investigated different aspects of platelet biology and have at times reported contrasting results. The general state of affairs is that platelet anomalies are not considered to be causal for migraine and that this topic merits additional investigation to gain a fuller understanding [181].

\section{Biochemical studies of serotonin in plasma}

Data regarding serotonin levels in plasma of migraineurs should be treated with caution due to differing definitions of plasma serotonin and determination of serotonin content in plasma. This is because normal blood plasma is composed of two distinguishable fractions namely platelet-rich-plasma (PRP) and platelet-poor plasma (PPP) [182]. Platelet-rich-plasma is blood plasma that is mostly bound to platelets whereas platelet-poor plasma refers to the fraction of freely circulating serotonin which is said to be distinct to PRP. This fraction of blood plasma contains a very low number of platelets and is identified as the extraplatelet pool [183]. This portion of plasma is difficult to assay consistently owing to the difficulty of preparing PPP without causing release of serotonin from platelets and without platelet contamination. Additionally, whether or not a study is using PPP or a less refined plasma subset is often unclear, adding to uncertainty [183]. This is perhaps demonstrated in the contrasting results that have been obtained with a few studies reporting elevated levels of plasma serotonin, specifically studies by Dvilansky et al., 1976, Ferrari et al., 1989 and Milovanovic et al., 1999 [184-186] (see Tables 3 and 4). Conversely studies by Curran et al., [187], Rydzewski, [188] and Nagata et al., [189] reported lower levels of plasma serotonin in migraineurs than in controls during the attack. More consistency and standardised methods of assaying blood plasma in biochemical studies are required in order to move forward.

\section{Biochemical studies of serotonin in urine}

In addition to the studies examining serotonin metabolism in CSF, saliva, platelets and plasma there have been several studies using urine as a proxy for serotonin activity in the brain. These were often the first studies and were fundamental in highlighting a possible serotonindependent mechanism urging further investigation [17]. Four out of seven independent studies observed an increase in the urinary excretion of the main metabolite of serotonin, 5-hydroxyindoleacetic acid (5-HIAA), in association with migraine attacks $[17,149,190,177]$ (see Table 5). Two studies [186, 191] reported a decrease in urinary excretion of 5-HIAA and one study reported no difference [192]. Bousser et al., [191] provided evidence of a $31 \%$ lowered urinary 5-HIAA excretion in 44 young adult female migraine patients between attacks and in 33 healthy age- and sex-matched control subjects [191]. Milovanovic et al., [173] reported a similar trend of lowered urinary 5-HIAA excretion although the sample size in this study was smaller consisting of a total of $18 \mathrm{mi}-$ graine patients [186]. Despite urine's ease of access, only a small number of studies have thus far investigated the biochemistry of urine in migraineurs.

\section{Biochemical model of serotonin}

The existing data support the premise that serotonin is low interictally but increased ictally (during attacks themselves) in the migraine brain [143, 196]. According to this model, during an attack serotonin is released from platelets into blood plasma causing a short-lived increase in free plasma serotonin that raises serotonin 


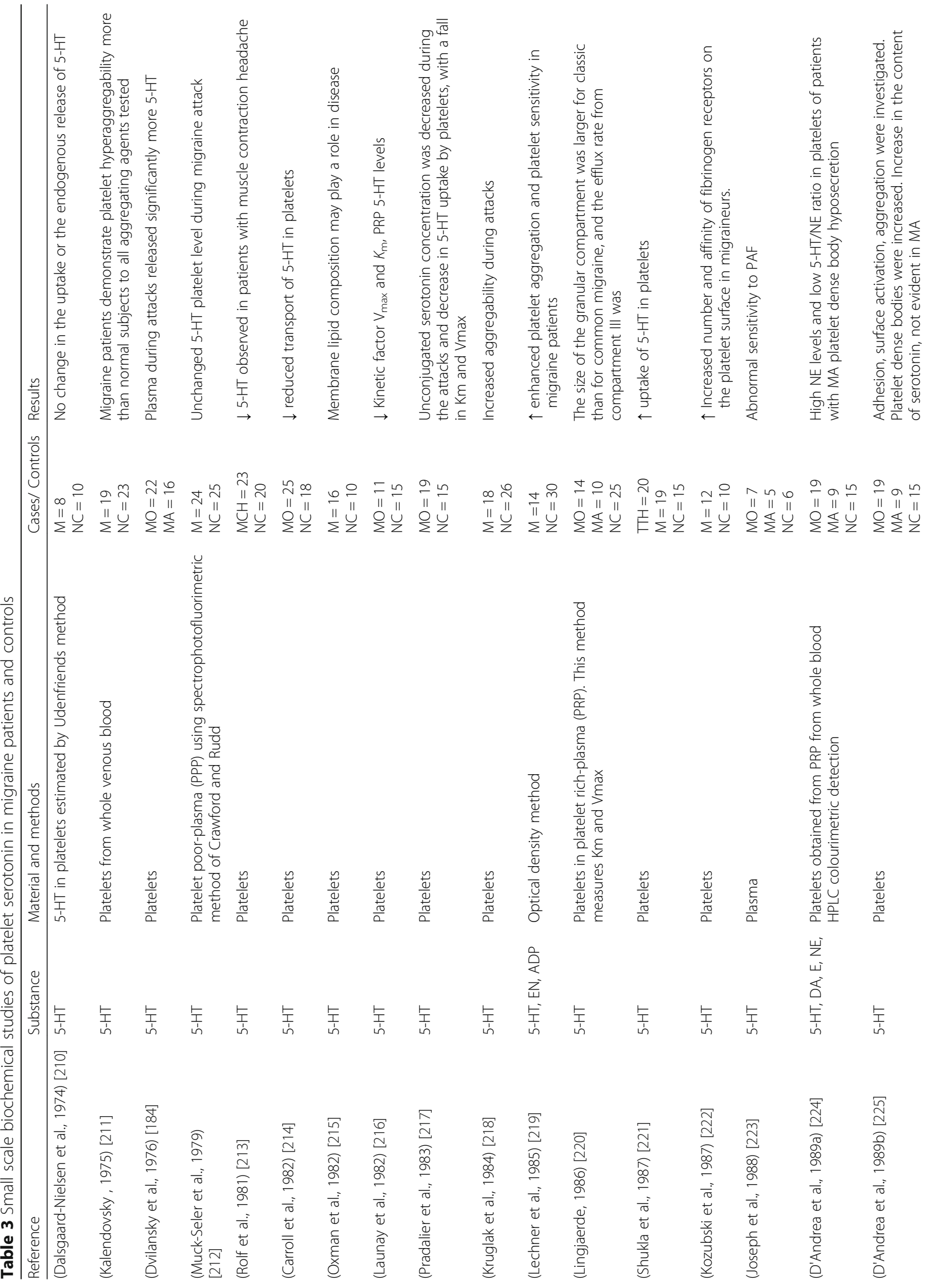




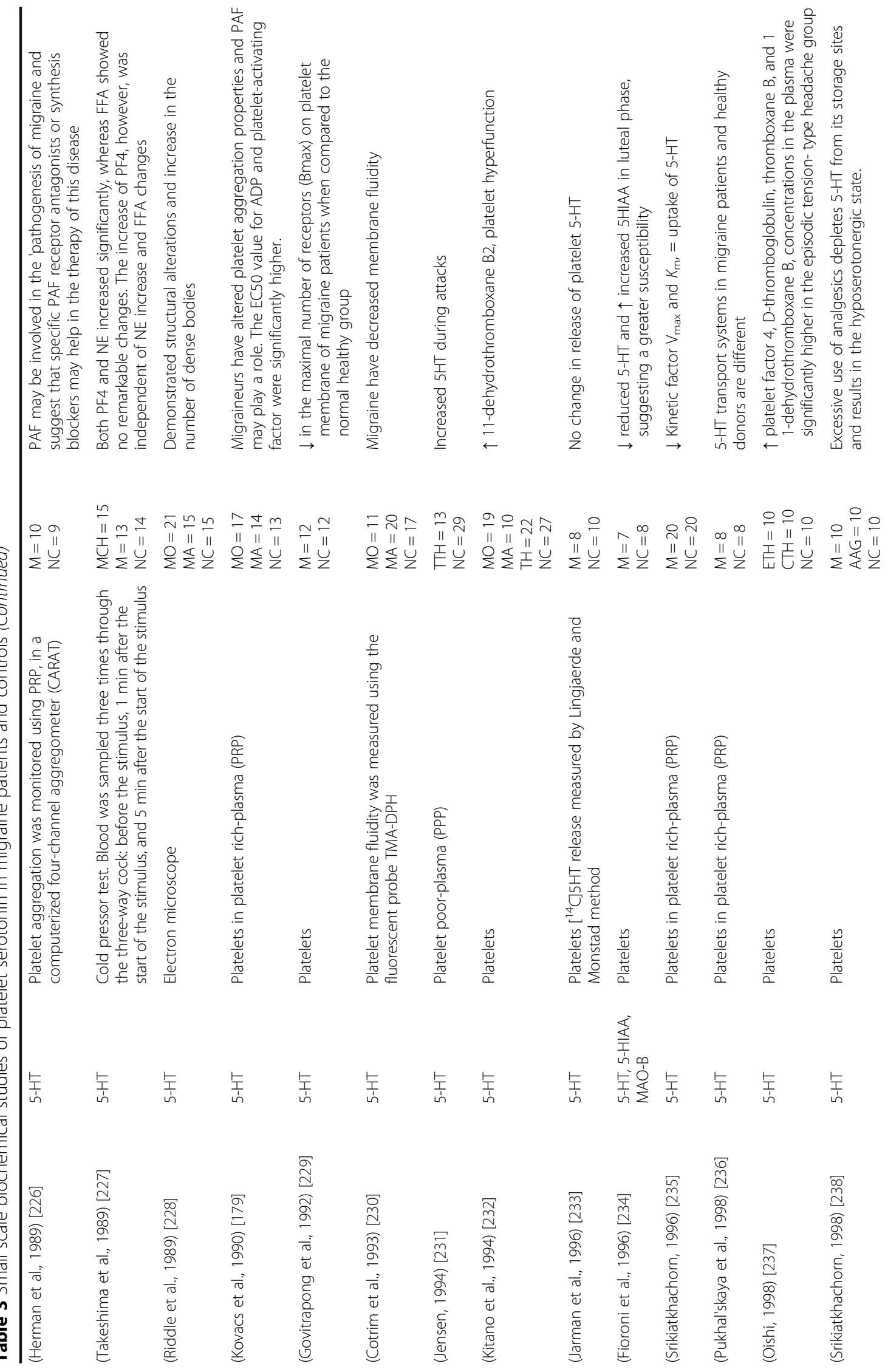




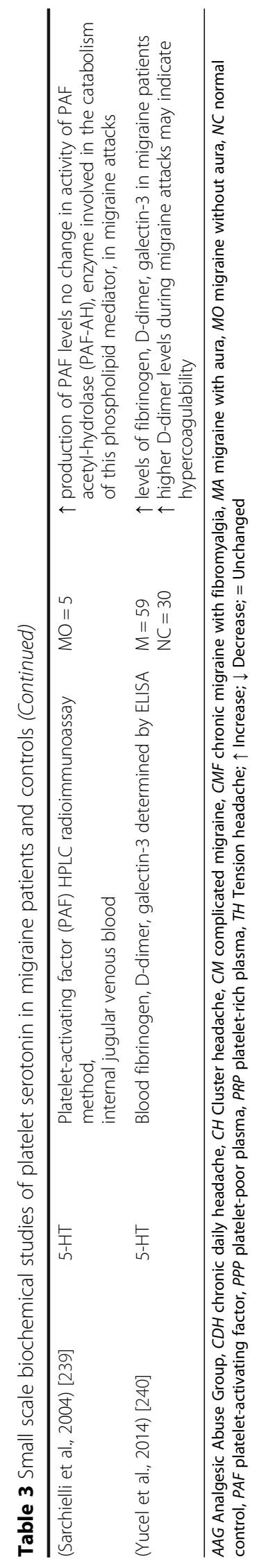




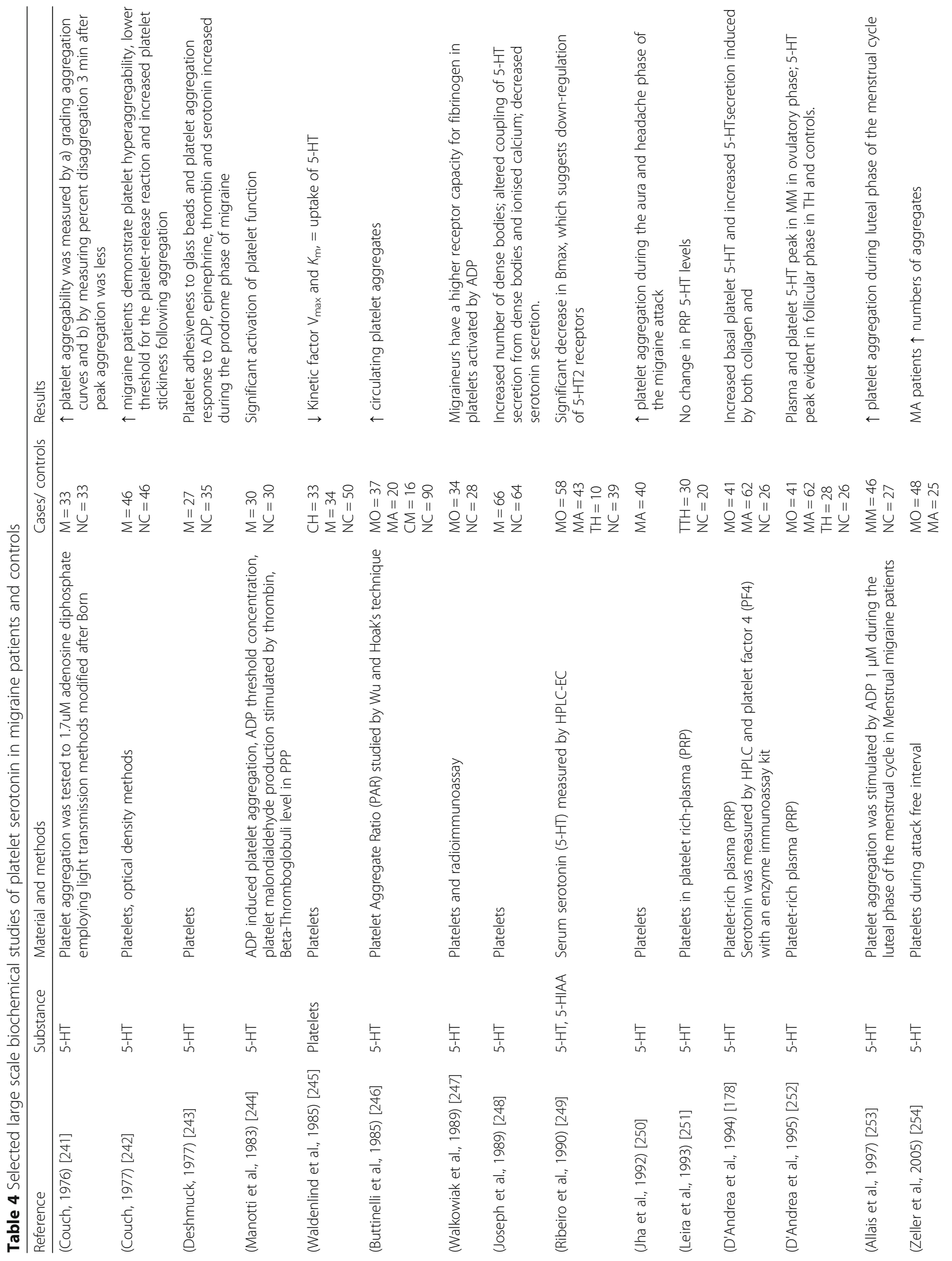




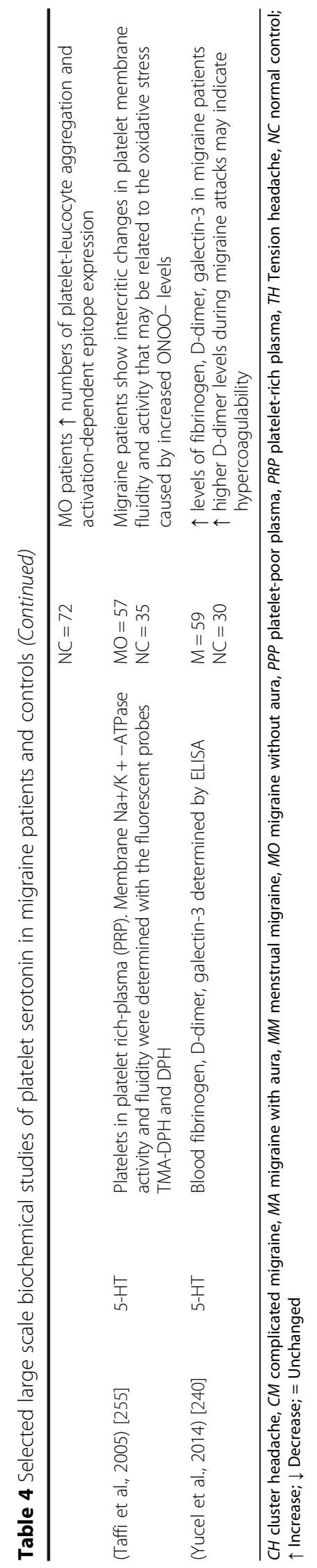


Table 5 Biochemical studies of 5-hydroxyindoleacetic acid (5-HIAA) in the urine of migraine patients and controls

\begin{tabular}{|c|c|c|c|c|c|c|c|}
\hline Reference & Migraine classification & Controls/cases & Sample tested & Levels & Controls/cases & Sample tested & Levels \\
\hline \multirow[t]{2}{*}{ (Sicuteri et al., 1961) [17] } & Not reported & Controls: 15 & Urine & & & & \\
\hline & & M: 15 & & $\uparrow$ & & & \\
\hline \multirow[t]{2}{*}{ (Curran et al., 1965) [187] } & Not reported & Controls: 10 & Urine & & Controls: 21 & Plasma & \\
\hline & & M: 18 & & $\uparrow$ & M: 11 & & $\downarrow$ \\
\hline \multirow[t]{2}{*}{ (Curzon et al., 1966) [149] } & Not reported & Controls: 4 & Urine & & & & \\
\hline & & M: 9 & & $=$ & & & \\
\hline \multirow[t]{2}{*}{ (Kangasni et al., 1972) [149] } & Not reported & Controls: 6 & Urine & & Controls: 6 & CSF & \\
\hline & & M: 9 & & $\uparrow$ & M: 14 & & $\uparrow$ \\
\hline \multirow[t]{2}{*}{ (Deanovic et al., 1975) [190] } & (Headache, 1962) [193] & Controls: 4 & Urine & & & & \\
\hline & & M: 14 & & $\uparrow$ & & & \\
\hline \multirow[t]{2}{*}{ (Bousser et al., 1986) [191] } & (Headache, 1970) [194] & Controls: 33 & Urine & & & & \\
\hline & & M: 44 & & $\downarrow$ & & & \\
\hline \multirow[t]{3}{*}{ (Milovanovic et al., 1999) [186] } & (ICHD-I, 1988) [195] & Controls: 11 & Urine & & Controls: 5 & Plasma & \\
\hline & & M: 8 & & $\downarrow$ & M: 5 & & $\uparrow$ \\
\hline & & TTH: 10 & & $\downarrow$ & TTH: 7 & & \\
\hline
\end{tabular}

M migraine, CSF cerebrospinal fluid, TTH Tension-Type Headache; $\uparrow$ Increase; $\downarrow$ Decrease; = Unchanged

levels in the brain [197]. The second arm of the model posits that raised levels of serotonin in the brain, during a migraine attack, exerts a vasoconstrictor effect on intracerebral arteries initiating the aura phase and cerebral ischemia with resulting visual disturbances. The concentration of serotonin eventually lowers because serotonin is broken down and excreted and this lowering postattack is thought to produce vasodilation of extracerebral arteries causing headache and pain [197]. Migraine is generally regarded as a low serotonin syndrome. Diminished levels of serotonin in the brain lower the threshold for pain and are evident in some disorders co-morbid with migraine including chronic tension headache [198] and depression [199] as well as other chronic diseases such as fibromyalgia, irritable bowel syndrome [200], premenstrual dysphoric disorder and depression. In addition, tricyclic antidepressants can also reduce the frequency of migraine attacks by increasing serotonin signalling further supporting a role for serotonin in the pathobiology of migraine [201]. Serotonin has also been implicated in CSD and the trigeminovascular pathway. Experimental depletion of serotonin in rats, enhances the development of CSD with accompanying cerebrovascular changes and increases responsiveness and sensitivity of the trigeminal system [202-204].

Metabolomics is an emerging field that has recently shown that variations in brain metabolic homeostasis are associated with neurological disorders $[205,206]$. In particular a recent study by Shyti et al., [191] identified metabolic changes by mass spectrometry in a transgenic mouse model of hemiplegic migraine after experimentally induced
CSD [207]. This is the first study demonstrating CSDinduced metabolite differences in Familial Hemiplegic Migraine type $1 \mathrm{R} 192 \mathrm{Q}$ mice relative to WT mice and that these events can be captured beyond the CNS in plasma samples. Although we still do not know what the connection of central and peripheral serotonergic changes in migraine may be, further study based on metabolic profiling of biological fluids which contain the "products of numerous genome-wide and proteome-wide interactions" [208], the 'metabolome' [209] will continue to shed light on the inner workings of the migraine brain. To study serotonin deficiency-associated mechanisms a study by Weng et al., used a metabolomics approach to identify biomarkers from serotonin deficient mice [47]. The mice were depleted of serotonin via two approaches (1) use of pchlorophenylalanine (pCPA) to pharmacologically inhibit tryptophan hydroxylase (Tph), a rate-limiting enzyme in serotonin biosynthesis and (2) genetic knockout of the $\mathrm{Tph} 2$ isoform. In this study serotonin deficiency was associated with altered energy metabolism and several biomarkers were identified in the serotonin deficient mice to be significantly altered compared with the control mice [47]. Moreover, the combination of sensitive brain imaging techniques and metabolomics platforms hold optimism to identify novel metabolite-gene relationships and new insight into small molecular changes in neuronal metabolism to enhance our understanding of biochemical pathways "functional readout". Pharmacometabolomicsinformed pharmacogenomics studies will therefore occupy an important position in the coming tide of molecular and "omics" research. 


\section{Conclusion}

The evidence so far points to migraine as a biochemically complex disorder involving several neurotransmitter systems which converge in their synaptic pathways. The general trend observed is that migraine patients have alterations of neurotransmitters in biological fluids with different biochemistry from controls, however the interpretation of the biological significance of these peripheral changes is unresolved. At present, despite the observation of biochemical alterations, specific diagnostic markers are lacking for this disorder. In addition MA and MO sufferers may exhibit varying degrees and types of neurotransmitter dysfunction due to differing neurological features of both migraine types which may be related to the aetiology and underlying genetic component of each migraine subtype. Insufficient serotonergic input due to changes in synthesis, release, receptor function/ expression, reuptake and transport in the brain and throughout the body may contribute to vulnerability to migraine. Genetic studies have highlighted involvement of the serotonin transporter gene SERT in migraine susceptibility. However, serotonergic biochemistry is complex and evidently a multiplicity of factors, rather than any single one, combine to result in migraine phenotypes. More research is required to shed light on the course of these various biochemical phenomena and enable more robust conclusions on causal relationships. The absence of modern biochemical studies underscores the need for more rigorously conducted research utilizing larger sample sizes, updated IHS classification criteria and more sensitive bioassays and instruments and standardized methods for sample collection, preparation/analysis. Novel approaches for investigating the serotonergic system using PET imaging technology integrated with a metabolomics and systems biology platform may help to better understand the biochemical milieu and metabolome of migraineurs and establish if the biochemical changes are linked to the clinical presentation of the disease process. In conclusion, given the therapeutic efficacy of triptans, investigating the functionality of the serotonergic system in the migraine brain remains on the agenda to illuminate disease pathomechanisms and new lines of treatment to enable a superior understanding of the disease process that will further aid in the diagnosis, treatment and management of migraine and headache related disorders.

\footnotetext{
Abbreviations

5-HIAA: 5-hydroxyindoleacetic acid; AAG: Analgesic abuse group; CDH: Chronic daily headache; $\mathrm{CH}$ : Cluster headache; CM: Complicated migraine; CMF: Chronic migraine with fibromyalgia; CSD: Cortical spreading depression; CSF: Cerebrospinal fluid; MA: Migraine with aura; MM: Menstrual migraine; MO: Migraine without aura; NC: Normal control; PPP: Platelet-poor plasma; PRP: Platelet-rich plasma; $\mathrm{TH}$ : Tension headache
}

\section{Acknowledgements}

Claudia Gasparini was the recipient of a Griffith University Postgraduate scholarship. We dedicate this review to pay tribute to Federigo Sicuteri for his seminal contribution to migraine research.

\section{Authors' contributions}

CG conceived and designed the review, drafted the manuscript and revised it for intellectual content. RS and LG revised the manuscript for intellectual content and provided essential comments to finalize the manuscript.

All authors read and approved the final manuscript.

\section{Competing interests}

The authors declare that they have no competing interests.

\section{Consent for publication}

Not applicable.

\section{Ethics approval and consent to participate}

Not applicable.

\section{Author details}

${ }^{1}$ Menzies Health Institute Queensland, Griffith University Gold Coast, Parklands Drive, Southport, QLD 4222, Australia. ${ }^{2}$ Genomics Research Centre, Institute of Health and Biomedical Innovation, School of Biomedical Sciences, Queensland University of Technology, Musk Ave, Kelvin Grove, QLD 4059, Australia.

Received: 11 October 2016 Accepted: 9 December 2016

Published online: 13 February 2017

\section{References}

1. Vos T, Flaxman AD, Naghavi M, Lozano R, Michaud C, Ezzati M, Shibuya K, Salomon JA, Abdalla S, Aboyans V, Abraham J, Ackerman I, Aggarwal R, Ahn SY, Ali MK, Alvarado M, Anderson HR, Anderson LM, Andrews KG, Atkinson C, Baddour LM, Bahalim AN, Barker-Collo S, Barrero LH, Bartels DH, Basanez MG, Baxter A, Bell ML, Benjamin EJ, Bennett D, Bernabe E, Bhalla K, Bhandari B, Bikbov B, Bin Abdulhak A, Birbeck G, Black JA, Blencowe H, Blore JD, Blyth F, Bolliger I, Bonaventure A, Boufous S, Bourne R, Boussinesq M, Braithwaite T, Brayne C, Bridgett L, Brooker S, Brooks P, Brugha TS, Bryan-Hancock C, Bucello C, Buchbinder R, Buckle G, Budke CM, Burch M, Burney P, Burstein R, Calabria B, Campbell B, Canter CE, Carabin H, Carapetis J, Carmona L, Cella C, Charlson F, Chen H, Cheng AT, Chou D, Chugh SS, Coffeng LE, Colan SD, Colquhoun S, Colson KE, Condon J, Connor MD, Cooper LT, Corriere M, Cortinovis M, de Vaccaro KC, Couser W, Cowie BC, Criqui MH, Cross M, Dabhadkar KC, Dahiya M, Dahodwala N, Damsere-Derry J, Danaei G, Davis A, De Leo D, Degenhardt L, Dellavalle R, Delossantos A, Denenberg J, Derrett S, Des Jarlais DC, Dharmaratne SD, Dherani M, Diaz-Torne C, Dolk H, Dorsey ER, Driscoll T, Duber H, Ebel B, Edmond K, Elbaz A, Ali SE, Erskine H, Erwin PJ, Espindola P, Ewoigbokhan SE, Farzadfar F, Feigin V, Felson DT, Ferrari A, Ferri CP, Fevre EM, Finucane MM, Flaxman S, Flood L, Foreman K, Forouzanfar MH, Fowkes FG, Franklin R, Fransen M, Freeman MK, Gabbe BJ, Gabriel SE, Gakidou E, Ganatra HA, Garcia B, Gaspari F, Gillum RF, Gmel G, Gosselin R, Grainger R, Groeger J, Guillemin F, Gunnell D, Gupta R, Haagsma J, Hagan H, Halasa YA, Hall W, Haring D, Haro JM, Harrison JE, Havmoeller R, Hay RJ, Higashi H, Hill C, Hoen B, Hoffman H, Hotez PJ, Hoy D, Huang JJ, Ibeanusi $\mathrm{SE}$, Jacobsen $\mathrm{KH}$, James $\mathrm{SL}$, Jarvis $\mathrm{D}$, Jasrasaria $\mathrm{R}$, Jayaraman $\mathrm{S}$, Johns N, Jonas JB, Karthikeyan G, Kassebaum N, Kawakami N, Keren A, Khoo $J P$, King $\mathrm{CH}$, Knowlton LM, Kobusingye $\mathrm{O}$, Koranteng A, Krishnamurthi $\mathrm{R}$, Lalloo R, Laslett LL, Lathlean T, Leasher JL, Lee YY, Leigh J, Lim SS, Limb E, Lin JK, Lipnick M, Lipshultz SE, Liu W, Loane M, Ohno SL, Lyons R, Ma J, Mabweijano J, Macintyre MF, Malekzadeh R, Mallinger L, Manivannan S, Marcenes W, March L, Margolis DJ, Marks GB, Marks R, Matsumori A, Matzopoulos R, Mayosi BM, McAnulty JH, McDermott MM, McGill N, McGrath J, Medina-Mora ME, Meltzer M, Mensah GA, Merriman TR, Meyer AC, Miglioli V, Miller M, Miller TR, Mitchell PB, Mocumbi AO, Moffitt TE, Mokdad AA, Monasta L, Montico M, Moradi-Lakeh M, Moran A, Morawska L, Mori R, Murdoch ME, Mwaniki MK, Naidoo K, Nair MN, Naldi L, Narayan KM, Nelson PK, Nelson RG, Nevitt MC, Newton CR, Nolte S, Norman P, Norman R, O'Donnell M, O'Hanlon S, Olives C, Omer SB, Ortblad K, Osborne R, Ozgediz D, Page A, Pahari B, Pandian JD, Rivero AP, Patten SB, Pearce N, 
Padilla RP, Perez-Ruiz F, Perico N, Pesudovs K, Phillips D, Phillips MR, Pierce K, Pion S, Polanczyk GV, Polinder S, Pope CA III, Popova S, Porrini E, Pourmalek F, Prince M, Pullan RL, Ramaiah KD, Ranganathan D, Razavi H, Regan M, Rehm JT, Rein DB, Remuzzi G, Richardson K, Rivara FP, Roberts T, Robinson C, De Leon FR, Ronfani L, Room R, Rosenfeld LC, Rushton L, Sacco RL, Saha S, Sampson U, Sanchez-Riera L, Sanman E, Schwebel DC, Scott JG, Segui-Gomez M, Shahraz S, Shepard DS, Shin H, Shivakoti R, Singh D, Singh GM, Singh JA, Singleton J, Sleet DA, Sliwa K, Smith E, Smith JL, Stapelberg NJ, Steer A, Steiner T, Stolk WA, Stovner LJ, Sudfeld C, Syed S, Tamburlini G, Tavakkoli M, Taylor HR, Taylor JA, Taylor WJ, Thomas B, Thomson WM, Thurston GD, Tleyjeh IM, Tonelli M, Towbin JA, Truelsen T, Tsilimbaris MK, Ubeda C, Undurraga EA, van der Werf MJ, van Os J, Vavilala MS, Venketasubramanian N, Wang M, Wang W, Watt K, Weatherall DJ, Weinstock MA, Weintraub R, Weisskopf MG, Weissman MM, White RA, Whiteford H, Wiersma ST, Wilkinson JD, Williams HC, Williams SR, Witt E, Wolfe F, Woolf AD, Wulf S, Yeh PH, Zaidi AK, Zheng ZI, Zonies D, Lopez AD, Murray CJ, AIMazroa MA, Memish ZA (2012) Years lived with disability (YLDs) for 1160 sequelae of 289 diseases and injuries 1990-2010: a systematic analysis for the global burden of disease study 2010. Lancet 380(9859):2163-2196. doi: 10.1016/s0140-6736(12)

2. IHS (2013) The international classification of headache disorders, 3rd edition (beta version). Cephalalgia 33(9):629-808. doi:10.1177/0333102413485658

3. Stovner LJ, Hagen K (2006) Prevalence, burden, and cost of headache disorders. Curr Opin Neurol 19(3):281-285. doi:10.1097/01.wco.0000227039. 16071.92

4. Malone CD, Bhowmick A, Wachholtz AB (2015) Migraine: treatments, comorbidities, and quality of life, in the USA. J Pain Res 8:537-547. doi:10. 2147/JPR.S88207

5. Buse DC, Loder EW, Gorman JA, Stewart WF, Reed ML, Fanning KM, Serrano D, Lipton RB (2013) Sex differences in the prevalence, symptoms, and associated features of migraine, probable migraine and other severe headache: results of the American migraine prevalence and prevention (AMPP) study. Headache 53(8):1278-1299. doi:10.1111/head.12150

6. Gasparini CF, Sutherland HG, Griffiths LR (2013) Studies on the pathophysiology and genetic basis of migraine. Curr Genomics 14(5):300-315

7. Vecsei L, Majlath Z, Balog A, Tajti J (2015) Drug targets of migraine and neuropathy: treatment of hyperexcitability. CNS Neurol Disord Drug Targets 14(5):664-676

8. Costa C, Tozzi A, Rainero I, Cupini LM, Calabresi P, Ayata C, Sarchielli P (2013) Cortical spreading depression as a target for anti-migraine agents. J Head Pain 14. doi:10.1186/1129-2377-14-62.

9. Burstein $R$, Jakubowski M, Rauch SD (2011) The science of migraine. J Vestib Res 21(6):305-314. doi:10.3233/ves-2012-0433

10. Aggarwal M, Puri V, Puri S (2012) Serotonin and CGRP in migraine. Ann Neurosci 19(2):88-94. doi:10.5214/ans.0972.7531.12190210

11. Persico AM, Verdecchia M, Pinzone V, Guidetti V (2014) Migraine genetics: current findings and future lines of research. Neurogenetics. doi:10.1007/ s10048-014-0433-x.

12. Rosenberg SS, Spitzer NC (2011) Calcium signaling in neuronal development. Cold Spring Harb Perspect Biol 3(10):a004259. doi:10.1101/ cshperspect.a004259

13. Daubert EA, Condron BG Serotonin: a regulator of neuronal morphology and circuitry. Trends Neurosci 33 (9):424-434. doi:10.1016/j.tins.2010.05.005

14. Boyer N, Dallel R, Artola A, Monconduit L (2014) General trigeminospinal central sensitization and impaired descending pain inhibitory controls contribute to migraine progression. Pain 155(7):1196-1205. doi:10.1016/.jpain.2014.03.001

15. Yan J, Dussor G (2014) Ion channels and migraine. Headache 54(4):619-639. doi:10.1111/head.12323

16. Friedrich T, Tavraz NN, Junghans C (2016) ATP1A2 mutations in migraine: seeing through the facets of an lon pump onto the neurobiology of disease. Front Physiol 7:239. doi:10.3389/fphys.2016.00239

17. Sicuteri F, Anselmi B, Testi A (1961) Biochemical investigations in headache: increase in hydroxyindoleactic acid excretion during migraine attacks. Int Arch Allergy Appl Immunol 19(1):55-58

18. Hoyer D, Hannon JP, Martin GR (2002) Molecular, pharmacological and functional diversity of 5-HT receptors. Pharmacol Biochem Behav 71(4):533-554

19. Gothert M, Schlicker E (1987) Classification of serotonin receptors. J Cardiovasc Pharmacol 10(Suppl 3):S3-7

20. Usman HO, Balaban CD (2016) Distribution of 5-HT1F Receptors in Monkey Vestibular and Trigeminal Ganglion Cells. Frontiers in Neurology 7 (173). doi: 10.3389/fneur.2016.00173
21. Booij L, Tremblay RE, Szyf M, Benkelfat C (2015) Genetic and early environmental influences on the serotonin system: consequences for brain development and risk for psychopathology. J Psychiatry Neurosci 40(1):5-18 doi:10.1503/jpn.140099

22. Lesch KP, Heils A (2000) Serotonergic gene transcriptional control regions: targets for antidepressant drug development? int j neuropsychopharmacol 3(1):67-79. doi:10.1017/s1461145700001747

23. Nordquist N, Oreland L (2010) Serotonin, genetic variability, behaviour, and psychiatric disorders-a review. Ups J Med Sci 115(1):2-10. doi:10.3109/ 03009730903573246

24. Collier DA, Stober G, Li T, Heils A, Catalano M, Di Bella D, Arranz MJ, Murray RM, Vallada HP, Bengel D, Muller CR, Roberts GW, Smeraldi E, Kirov G, Sham P, Lesch KP (1996) A novel functional polymorphism within the promoter of the serotonin transporter gene: possible role in susceptibility to affective disorders. Mol Psychiatry 1(6):453-460

25. Heils A, Teufel A, Petri S, Stober G, Riederer P, Bengel D, Lesch KP (1996) Allelic variation of human serotonin transporter gene expression. J Neurochem 66(6):2621-2624

26. Sabol SZ, Hu S, Hamer D (1998) A functional polymorphism in the monoamine oxidase a gene promoter. Hum Genet 103(3):273-279

27. Schurks M, Rist PM, Kurth T (2010) STin2 VNTR polymorphism in the serotonin transporter gene and migraine: pooled and meta-analyses. J Headache Pain 11(4):317-326. doi:10.1007/s10194-010-0230-3

28. Liu H, Liu M, Wang Y, Wang XM, Qiu Y, Long JF, Zhang SP (2011) Association of 5-HTT gene polymorphisms with migraine: a systematic review and meta-analysis. J Neurol Sci J Neurol Sci 305(1-2):57-66. doi:10. 1016/j.jns.2011.03.016

29. Schurks M, Rist PM, Kurth T (2010) 5-HTTLPR polymorphism in the serotonin transporter gene and migraine: a systematic review and meta-analysis. Cephalalgia 30(11):1296-1305. doi:10.1177/0333102410362929

30. Yilmaz M, Erdal ME, Herken H, Cataloluk O, Barlas O, Bayazit YA (2001) Significance of serotonin transporter gene polymorphism in migraine. J Neurol Sci 186(1-2):27-30

31. Juhasz G, Zsombok T, Laszik A, Gonda X, Sotonyi P, Faludi G, Bagdy G (2003) Association analysis of 5-HTTLPR variants, 5-HT2a receptor gene $102 \mathrm{~T} / \mathrm{C}$ polymorphism and migraine. J Neurogenet 17(2-3):231-240

32. Borroni B, Brambilla C, Liberini P, Rao R, Archetti S, Gipponi S, Volta GD, Padovani A (2005) Functional serotonin 5-HTTLPR polymorphism is a risk factor for migraine with aura. J Headache Pain 6(4):182-184. doi:10.1007/ s10194-005-0179-9

33. Marziniak M, Mossner R, Schmitt A, Lesch KP, Sommer C (2005) A functional serotonin transporter gene polymorphism is associated with migraine with aura. Neurology 64(1):157-159. doi:10.1212/01.WNL.0000148597.52312.9E

34. Todt U, Freudenberg J, Goebel I, Heinze A, Heinze-Kuhn K, Rietschel M, Gobel H, Kubisch C (2006) Variation of the serotonin transporter gene SLC6A4 in the susceptibility to migraine with aura. Neurology 67(9):17071709. doi:10.1212/01.wnl.0000242883.96822.93

35. Corominas R, Sobrido MJ, Ribases M, Cuenca-Leon E, Blanco-Arias P, Narberhaus B, Roig M, Leira R, Lopez-Gonzalez J, Macaya A, Cormand B (2010) Association study of the serotoninergic system in migraine in the Spanish population. Am J Med Genet B Neuropsychiatr Genet 153B(1):177184. doi:10.1002/ajmg.b.30972

36. Ogilvie AD, Russell MB, Dhall P, Battersby S, Ulrich V, Smith CA, Goodwin GM, Harmar AJ, Olesen J (1998) Altered allelic distributions of the serotonin transporter gene in migraine without aura and migraine with aura. Cephalalgia 18(1):23-26

37. Peng JM, Yu YJ, Su LD, Luo X (2014) Meta-analysis of 5-hydroxytryptamine type $2 \mathrm{~A}$ receptor polymorphisms and migraine susceptibility. Int J Neurosci 124(12):882-889. doi:10.3109/00207454.2014.888425

38. Gormley P, Anttila V, Winsvold BS, Palta P, Esko T, Pers TH, Farh KH, CuencaLeon E, Muona M, Furlotte NA, Kurth T, Ingason A, McMahon G, Ligthart L, Terwindt GM, Kallela M, Freilinger TM, Ran C, Gordon SG, Stam AH, Steinberg S, Borck G, Koiranen M, Quaye L, Adams HH, Lehtimaki T, Sarin AP, Wedenoja J, Hinds DA, Buring JE, Schurks M, Ridker PM, Hrafnsdottir MG, Stefansson H, Ring SM, Hottenga JJ, Penninx BW, Farkkila M, Artto V, Kaunisto M, Vepsalainen S, Malik R, Heath AC, Madden PA, Martin NG, Montgomery GW, Kurki MI, Kals M, Magi R, Parn K, Hamalainen E, Huang H, Byrnes AE, Franke L, Huang J, Stergiakouli E, Lee PH, Sandor C, Webber C, Cader Z, Muller-Myhsok B, Schreiber S, Meitinger T, Eriksson JG, Salomaa V, Heikkila K, Loehrer E, Uitterlinden AG, Hofman A, van Duijn CM, Cherkas L, Pedersen LM, Stubhaug A, Nielsen CS, Mannikko M, Mihailov E, Milani L, 
Gobel H, Esserlind AL, Christensen AF, Hansen TF, Werge T, Kaprio J, Aromaa AJ, Raitakari O, Ikram MA, Spector T, Jarvelin MR, Metspalu A, Kubisch C, Strachan DP, Ferrari MD, Belin AC, Dichgans M, Wessman M, van den Maagdenberg AM, Zwart JA, Boomsma DI, Smith GD, Stefansson K, Eriksson N, Daly MJ, Neale BM, Olesen J, Chasman DI, Nyholt DR, Palotie A (2016) Meta-analysis of 375,000 individuals identifies 38 susceptibility loci for migraine. Nat Genet 48(8):856-866. doi:10.1038/ng.3598

39. Thompson MD, Noble-Topham S, Percy ME, Andrade DM, Ebers GC (2012) Chromosome $1 \mathrm{p} 36$ in migraine with aura: association study of the $5 \mathrm{HT}(1 \mathrm{D})$ locus. Neuroreport 23(1):45-48. doi:10.1097/WNR.0b013e32834e5af3

40. Yucel Y, Coşkun S, Cengiz B, Ozdemir HH, Uzar E, Cim A, Camkurt MA, Aluclu MU (2016) Association of polymorphisms within the serotonin receptor genes 5 - HTR1A, 5 - HTR1B, 5 - HTR2A and 5 - HTR2C and migraine susceptibility in a Turkish population. Clin Psychopharmacol Neurosci 14(3):250-255

41. Hill MJ, Reynolds GP (2007) 5-HT2C receptor gene polymorphisms associated with antipsychotic drug action alter promoter activity. Brain Res 1149:14-17. doi:10.1016/j.brainres.2007.02.038

42. Marcus DA (1993) Serotonin and its role in headache pathogenesis and treatment. Clin J Pain 9(3):159-167

43. Jung A, Huge A, Kuhlenbaumer G, Kempt S, Seehafer T, Evers S, Berger K, Marziniak M (2010) Genetic TPH2 variants and the susceptibility for migraine: association of a TPH2 haplotype with migraine without aura. J neural transm 117(11):1253-1260. doi:10.1007/s00702-010-0468-6

44. Chen GL, Miller GM (2012) Advances in tryptophan hydroxylase-2 gene expression regulation: new insights into serotonin-stress interaction and clinical implications. Am J Med Genet B Neuropsychiatr Genet 159b(2):152171. doi:10.1002/ajmg.b.32023

45. Chen GL, Miller GM (2013) Tryptophan hydroxylase-2: an emerging therapeutic target for stress disorders. Biochem Pharmacol 85(9):1227-1233. doi:10.1016/j.bcp.2013.02.018

46. Abbar M, Courtet P, Bellivier F, Leboyer M, Boulenger JP, Castelhau D, Ferreira M, Lambercy C, Mouthon D, Paoloni-Giacobino A, Vessaz M, Malafosse A, Buresi C (2001) Suicide attempts and the tryptophan hydroxylase gene. Mol Psychiatry 6(3):268-273. doi:10.1038/sj.mp.4000846

47. Weng R, Shen S, Tian Y, Burton C, Xu X, Liu Y, Chang C, Bai Y, Liu H (2015) Metabolomics approach reveals integrated metabolic network associated with serotonin deficiency. Sci Rep 5:11864. doi:10.1038/srep11864

48. Gutknecht L, Waider J, Kraft S, Kriegebaum C, Holtmann B, Reif A, Schmitt A Lesch KP (2008) Deficiency of brain 5-HT synthesis but serotonergic neuron formation in Tph2 knockout mice. J neural transm 115(8):1127-1132. doi:10. 1007/s00702-008-0096-6

49. Pelosi B, Pratelli M, Migliarini S, Pacini G, Pasqualetti M (2015) Generation of a Tph2 conditional knockout mouse line for time- and tissue-specific depletion of brain serotonin. PLoS One 10(8):e0136422. doi:10.1371/journal. pone.0136422

50. Dussor G (2014) Serotonin, 5HT1 agonists, and migraine: new data, but old questions still not answered. Curr Opin Support Palliat Care 8(2):137-142. doi:10.1097/spc.0000000000000044

51. Ibrahimi K, Danser A, Terwindt G, van den Meiracker A, MaassenVanDenBrink A (2016) A human trigeminovascular biomarker for antimigraine drugs: A randomised, double-blind, placebo-controlled, crossover trial with sumatriptan. Cephalalgia. 0333102416637833

52. Ma QP, Hill R, Sirinathsinghji D (2001) Colocalization of CGRP with 5-HT1B/ $1 \mathrm{D}$ receptors and substance $\mathrm{P}$ in trigeminal ganglion neurons in rats. Eur J Neurosci 13(11):2099-2104

53. Rizzoli PB (2014) Emerging therapeutic options for acute migraine: focus on the potential of lasmiditan. Neuropsychiatr dis treat 10:547-552. doi:10. 2147/NDT.S25531

54. Harriott AM, Scheff NN, Gold MS (2012) The complex actions of sumatriptan on rat dural afferents. Cephalalgia 32(10):738-749. doi:10.1177/0333102412451356

55. Baillie LD, Ahn AH, Mulligan SJ (2012) Sumatriptan inhibition of N-type calcium channel mediated signaling in dural CGRP terminal fibres. Neuropharmacology 63(3):362-367. doi:10.1016/..neuropharm.2012.04.016

56. Evans MS, Cheng X, Jeffry JA, Disney KE, Premkumar LS (2012) Sumatriptan inhibits TRPV1 channels in trigeminal neurons. Headache 52(5):773-784. doi: 10.1111/j.1526-4610.2011.02053.x

57. Cameron C, Kelly S, Hsieh S-C, Murphy M, Chen L, Kotb A, Peterson J, Coyle D, Skidmore B, Gomes T, Clifford T, Wells G (2015) Triptans in the acute treatment of migraine: a systematic review and network meta-analysis. Headache 55:221-235. doi:10.1111/head.12601
58. Thorlund K, Mills EJ, Wu P, Ramos E, Chatterjee A, Druyts E, Goadsby PJ (2014) Comparative efficacy of triptans for the abortive treatment of migraine: a multiple treatment comparison meta-analysis. Cephalalgia 34(4): 258-267. doi:10.1177/0333102413508661

59. Hougaard A, Tfelt-Hansen P (2015) Review of dose-response curves for acute antimigraine drugs: triptans, 5-HT1F agonists and CGRP antagonists. Expert Opin Drug Metab Toxicol 11(9):1409-1418. doi:10.1517/17425255. 2015.1055244

60. Christensen AF, Esserlind A-L, Werge T, Stefánsson H, Stefánsson K, Olesen J (2015) The influence of genetic constitution on migraine drug responses. Cephalalgia. 0333102415610874

61. Gentile G, Chiossi L, Lionetto L, Martelletti P, Borro M (2014) Pharmacogenetic insights into migraine treatment in children. Pharmacogenomics 15(11):1539-1550. doi:10.2217/pgs.14.104

62. Buzzi MG (2008) Pathways to the best fit of triptans for migraine patients. Cephalalgia 28(Suppl 2):21-27. doi:10.1111/j.1468-2982.2008.01687.x

63. Gentile G, Borro M, Simmaco M, Missori S, Lala N, Martelletti P (2011) Gene polymorphisms involved in triptans pharmacokinetics and pharmacodynamics in migraine therapy. Expert Opin Drug Metab Toxicol 7(1):39-47. doi:10.1517/17425255.2011.538680

64. Terrazzino S, Viana M, Floriddia E, Monaco F, Mittino D, Sances G, Tassorelli C, Nappi G, Rinaldi M, Canonico PL, Genazzani AA (2010) The serotonin transporter gene polymorphism STin2 VNTR confers an increased risk of inconsistent response to triptans in migraine patients. Eur J Pharmacol 641(2-3):82-87. doi:10.1016/j.ejphar.2010.04.049

65. Anttila V, Winsvold BS, Gormley P, Kurth T, Bettella F, McMahon G, Kallela M, Malik R, de Vries B, Terwindt G, Medland SE, Todt U, McArdle WL, Quaye L Koiranen M, Ikram MA, Lehtimaki T, Stam AH, Ligthart L, Wedenoja J, Dunham I, Neale BM, Palta P, Hamalainen E, Schurks M, Rose LM, Buring JE, Ridker PM, Steinberg S, Stefansson H, Jakobsson F, Lawlor DA, Evans DM, Ring SM, Farkkila M, Artto V, Kaunisto MA, Freilinger T, Schoenen J, Frants RR, Pelzer N, Weller CM, Zielman R, Heath AC, Madden PA, Montgomery GW, Martin NG, Borck G, Gobel H, Heinze A, Heinze-Kuhn K, Williams FM, Hartikainen AL, Pouta A, van den Ende J, Uitterlinden AG, Hofman A, Amin N, Hottenga JJ, Vink JM, Heikkila K, Alexander M, Muller-Myhsok B, Schreiber S, Meitinger T, Wichmann HE, Aromaa A, Eriksson JG, Traynor BJ, Trabzuni D, Rossin E, Lage K, Jacobs SB, Gibbs JR, Birney E, Kaprio J, Penninx BW, Boomsma DI, van Duijn C, Raitakari O, Jarvelin MR, Zwart JA, Cherkas L, Strachan DP, Kubisch C, Ferrari MD, van den Maagdenberg AM, Dichgans M, Wessman M, Smith GD, Stefansson K, Daly MJ, Nyholt DR, Chasman DI, Palotie A (2013) Genome-wide meta-analysis identifies new susceptibility loci for migraine. Nat Genet 45(8):912-917. doi:10.1038/ng.2676

66. Gentile G, Borro M, Lala N, Missori S, Simmaco M, Martelletti P (2010) Genetic polymorphisms related to efficacy and overuse of triptans in chronic migraine. J Headache Pain 11(5):431-435. doi:10.1007/s10194-010-0241-0

67. Gentile G, Missori S, Borro M, Sebastianelli A, Simmaco M, Martelletti P (2010) Frequencies of genetic polymorphisms related to triptans metabolism in chronic migraine. J Headache Pain 11(2):151-156. doi:10. 1007/s10194-010-0202-7

68. Brandl EJ, Kennedy JL, Muller DJ (2014) Pharmacogenetics of antipsychotics. Can J Psychiatry 59(2):76-88

69. Everett JR (2016) From metabonomics to pharmacometabonomics: the role of metabolic profiling in personalized medicine. Front Pharmacol 7:297. doi: 10.3389/fphar.2016.00297

70. Ji Y, Biernacka JM, Hebbring S, Chai Y, Jenkins GD, Batzler A, Snyder KA, Drews MS, Desta Z, Flockhart D, Mushiroda T, Kubo M, Nakamura Y, Kamatani N, Schaid D, Weinshilboum RM, Mrazek DA (2013) Pharmacogenomics of selective serotonin reuptake inhibitor treatment for major depressive disorder: genome-wide associations and functional genomics. Pharmacogenomics J 13(5):456-463. doi:10.1038/tpj.2012.32

71. Gupta M, Neavin D, Liu D, Biernacka J, Hall-Flavin D, Bobo WV, Frye MA, Skime M, Jenkins GD, Batzler A, Kalari K, Matson W, Bhasin SS, Zhu H, Mushiroda T, Nakamura Y, Kubo M, Wang L, Kaddurah-Daouk R, Weinshilboum RM (2016) TSPAN5, ERICH3 and selective serotonin reuptake inhibitors in major depressive disorder: pharmacometabolomics-informed pharmacogenomics. Mol Psychiatry 21(12):1717-1725. doi:10.1038/mp.2016.6

72. Dunn CD, Sulis ML, Ferrando AA, Greenwald I (2010) A conserved tetraspanin subfamily promotes Notch signaling in Caenorhabditis elegans and in human cells. Proc Natl Acad Sci U S A 107(13):5907-5912. doi:10. 1073/pnas.1001647107 
73. Anthony M, Lance JW (1969) Monoamine oxidase inhibition in the treatment of migraine. Arch Neurol 21(3):263-268

74. Tfelt-Hansen PC, Pihl T, Hougaard A, Mitsikostas DD (2014) Drugs targeting 5hydroxytryptamine receptors in acute treatments of migraine attacks. A review of new drugs and new administration forms of established drugs. Expert Opin Investig Drugs 23(3):375-385. doi:10.1517/13543784.2014.861817

75. Farkkila M, Diener HC, Geraud G, Lainez M, Schoenen J, Harner N, Pilgrim A, Reuter U (2012) Efficacy and tolerability of lasmiditan, an oral 5-HT(1 F) receptor agonist, for the acute treatment of migraine: a phase 2 randomised, placebo-controlled, parallel-group, dose-ranging study. Lancet Neurol 11(5):405-413. doi:10.1016/s1474-4422(12)70047-9

76. Viguier F, Michot B, Hamon M, Bourgoin S (2013) Multiple roles of serotonin in pain control mechanisms -implications of 5-HT7 and other 5-HT receptor types. Eur J Pharmacol 716(1-3):8-16, http://dx.doi.org/10.1016/j. ejphar.2013.01.074

77. Guo W, Miyoshi K, Dubner R, Gu M, Li M, Liu J, Yang J, Zou S, Ren K, Noguchi K, Wei F (2014) Spinal 5-HT3 receptors mediate descending facilitation and contribute to behavioral hypersensitivity via a reciprocal neuron-glial signaling cascade. Mol Pain 10:35. doi:10.1186/1744-8069-10-35

78. Haahr ME, Fisher PM, Jensen CG, Frokjaer VG, Mahon BM, Madsen K, Baare WF, Lehel S, Norremolle A, Rabiner EA, Knudsen GM (2014) Central 5-HT4 receptor binding as biomarker of serotonergic tonus in humans: a [11C]SB207145 PET study. Mol Psychiatry 19(4):427-432. doi:10.1038/mp.2013.147

79. Vasefi MS, Yang K, Li J, Kruk JS, Heikkila JJ, Jackson MF, MacDonald JF, Beazely MA (2013) Acute 5-HT7 receptor activation increases NMDA-evoked currents and differentially alters NMDA receptor subunit phosphorylation and trafficking in hippocampal neurons. Mol Brain 6(1):1-9. doi:10.1186/ 1756-6606-6-24

80. Cho SY, Ki HG, Kim JM, Oh JM, Yang JH, Kim WM, Lee HG, Yoon MH, Choi JI (2015) Expression of the spinal 5-HT7 receptor and p-ERK pathway in the carrageenan inflammatory pain of rats. Korean J Anesthesiol 68(2):170-174. doi:10.4097/kjae.2015.68.2.170

81. Hedlund PB (2009) The 5-HT7 receptor and disorders of the nervous system: an overview. Psychopharmacology (Berl) 206(3):345-354

82. Jenkins TA, Nguyen JCD, Polglaze KE, Bertrand PP (2016) Influence of Tryptophan and Serotonin on Mood and Cognition with a Possible Role of the Gut-Brain Axis. Nutrients 8(1). doi:10.3390/nu8010056

83. Stone TW, Darlington LG (2002) Endogenous kynurenines as targets for drug discovery and development. Nat Rev Drug Discov 1(8):609-620. doi:10. 1038/nrd870

84. Richard DM, Dawes MA, Mathias CW, Acheson A, Hill-Kapturczak N, Dougherty DM (2009) L-tryptophan: basic metabolic functions, behavioral research and therapeutic indications. Int j tryptophan res 2:45-60

85. Schwarcz R, Bruno JP, Muchowski PJ, Wu H-Q (2012) Kynurenines in the mammalian brain: when physiology meets pathology. Nat Rev Neurosci 13(7):465-477. doi:10.1038/nrn3257

86. Fujigaki H, Yamamoto Y, Saito K (2016) L-Tryptophan-kynurenine pathway enzymes are therapeutic target for neuropsychiatric diseases: Focus on cell type differences. Neuropharmacology. doi:10.1016/j.neuropharm.2016.01.011

87. Linderholm KR, Skogh E, Olsson SK, Dahl M-L, Holtze M, Engberg G, Samuelsson M, Erhardt S (2012) Increased levels of kynurenine and kynurenic acid in the CSF of patients with schizophrenia. Schizophr Bull 38(3):426-432. doi:10.1093/schbul/sbq086

88. Curto M, Lionetto L, Negro A, Capi M, Perugino F, Fazio F, Giamberardino MA, Simmaco M, Nicoletti F, Martelletti P (2015) Altered serum levels of kynurenine metabolites in patients affected by cluster headache. Headache Pain 17(1):27. doi:10.1186/s10194-016-0620-2

89. Curto M, Lionetto L, Negro A, Capi M, Fazio F, Giamberardino MA, Simmaco M, Nicoletti F, Martelletti P (2015) Altered kynurenine pathway metabolites in serum of chronic migraine patients. J Headache Pain 17:47. doi:10.1186/ s10194-016-0638-5

90. Curto M, Lionetto L, Fazio F, Mitsikostas D-D, Martelletti P (2015) Fathoming the kynurenine pathway in migraine: why understanding the enzymatic cascades is still critically important. Intern Emerg Med 10(4):413-421. doi:10. 1007/s11739-015-1208-6

91. Vecsei L, Szalardy L, Fulop F, Toldi J (2013) Kynurenines in the CNS: recent advances and new questions. Nat Rev Drug Discov 12(1):64-82, http://www nature.com/nrd/journal/v12/n1/full/nrd3793.html

92. Carpenter LL, Anderson GM, Pelton GH, Gudin JA, Kirwin PDS, Price LH, Heninger GR, McDougle CJ (1998) Tryptophan depletion during continuous CSF sampling in healthy human subjects. Neuropsychopharmacology 19(1):26-35
93. Williams WA, Shoaf SE, Hommer D, Rawlings R, Linnoila M (1999) Effects of acute tryptophan depletion on plasma and cerebrospinal fluid tryptophan and 5-hydroxyindoleacetic acid in normal volunteers. J Neurochem 72(4): 1641-1647. doi:10.1046/j.1471-4159.1999.721641.x

94. Sánchez CL, Van Swearingen AED, Arrant AE, Biskup CS, Kuhn CM, Zepf FD (2015) Simplified dietary acute tryptophan depletion: effects of a novel amino acid mixture on the neurochemistry of C57BL/6 J mice. 59. doi:10. 3402/fnr.v59.27424

95. Biskup CS, Sanchez CL, Arrant A, Van Swearingen AE, Kuhn C, Zepf FD (2012) Effects of acute tryptophan depletion on brain serotonin function and concentrations of dopamine and norepinephrine in C57BL/6 J and BALB/cJ mice. PLoS One 7(5):e35916. doi:10.1371/journal.pone.0035916

96. Sanchez CL, Van Swearingen AE, Arrant AE, Kuhn CM, Zepf FD (2014) Dietary manipulation of serotonergic and dopaminergic function in C57BL/ 6 J mice with amino acid depletion mixtures. J neural transm 121(2):153162. doi:10.1007/s00702-013-1083-0

97. Eccleston D, Ashcroft GW, Crawford TB (1970) Effect of tryptophan administration on 5HIAA in cerebrospinal fluid in man. J Neurol Neurosurg Psychiatry 33(2):269-272

98. Young SN (2013) Acute tryptophan depletion in humans: a review of theoretical, practical and ethical aspects. J Psychiat Neurosci 38(5):294-305. doi:10.1503/jpn.120209

99. Young SN (2007) How to increase serotonin in the human brain without drugs. J Psychiat Neurosci 32(6):394-399

100. Rao TSS, Asha MR, Ramesh BN, Rao KSJ (2008) Understanding nutrition, depression and mental illnesses. Indian J Psychiatry 50(2):77-82. doi:10.4103/ 0019-5545.42391

101. Wurtman RJ (1987) Dietary treatments that affect brain neurotransmitters. Ann N Y Acad Sci 499(1):179-190. doi:10.1111/j.1749-6632.1987.tb36209.x

102. Drummond PD (2006) Tryptophan depletion increases nausea, headache and photophobia in migraine sufferers. Cephalalgia 26(10):1225-1233. doi: 10.1111/j.1468-2982.2006.01212.x

103. Kangasniemi P, Falck B, Langvik VA, Hyyppa MT (1978) Levotryptophan treatment in migraine. Headache 18(3):161-165

104. Steardo L, Sorge F, Florio C (1977) L-tryptophan treatment in essential headache: preliminary data. Acta Neurol (Napoli) 32(5):613-623

105. Shabbir F, Patel A, Mattison C, Bose S, Krishnamohan R, Sweeney E, Sandhu S, Nel W, Rais A, Sandhu R, Ngu N, Sharma S (2013) Effect of diet on serotonergic neurotransmission in depression. Neurochem Int 62(3):324329. doi:10.1016/j.neuint.2012.12.014

106. Gyermek L (1996) Pharmacology of serotonin as related to anesthesia. J Clin Anesth 8(5):402-425

107. Claustrat B, Loisy C, Brun J, Beorchia S, Arnaud JL, Chazot G (1989) Nocturnal plasma melatonin levels in migraine - a preliminary-report. Headache 29(4):242-245. doi:10.1111/j.1526-4610.1989.hed22904242.x

108. Murialdo G, Fonzi S, Costelli P, Solinas GP, Parodi C, Marabini S, Fanciullacci M, Polleri A (1994) Urinary melatonin excretion throughout the ovarian cycle in menstrually related migraine. Cephalalgia 14(3):205-209. doi:10. 1046/j.1468-2982.1994.014003205.x

109. Brun J, Claustrat B, Saddier P, Chazot G (1995) Nocturnal melatonin excretion is decreased in patients with migraine without aura attacks associated with menses. Cephalalgia 15(2):136-139. doi:10.1046/j.1468-2982. 1995.015002136.x

110. Bruera O, Sances G, Leston J, Levin G, Cristina S, Medina C, Barontini M, Nappi G, Figuerola MA (2008) Plasma melatonin pattern in chronic and episodic headaches: evaluation during sleep and waking. Funct Neurol 23(2):77-81

111. Peres MF, Sanchez del Rio M, Seabra ML, Tufik S, Abucham J, Cipolla-Neto J, Silberstein SD, Zukerman E (2001) Hypothalamic involvement in chronic migraine. J Neurol Neurosurg Psychiatry 71(6):747-751

112. Masruha MR, de Souza Vieira DS, Minett TS, Cipolla-Neto J, Zukerman E, Vilanova LC, Peres MF (2008) Low urinary 6-sulphatoxymelatonin concentrations in acute migraine. J Headache Pain 9(4):221-224. doi:10. 1007/s10194-008-0047-5

113. Masruha MR, Lin J, de Souza Vieira DS, Minett TS, Cipolla-Neto J, Zukerman E, Vilanova LC, Peres MF (2010) Urinary 6-sulphatoxymelatonin levels are depressed in chronic migraine and several comorbidities. Headache 50(3): 413-419. doi:10.1111/j.1526-4610.2009.01547.x

114. Singh M, Jadhav HR (2014) Melatonin: functions and ligands. Drug Discov Today 19(9):1410-1418. doi:10.1016/j.drudis.2014.04.014

115. Badawy A (2013) Novel nutritional treatment for manic and psychotic disorders: a review of tryptophan and tyrosine depletion studies and the 
potential of protein-based formulations using glycomacropeptide Psychopharmacology (Berl) 228(3):347-358. doi:10.1007/s00213-013-3191-9

116. Lu WZ, Gwee KA, Moochhalla S, Ho KY (2005) Melatonin improves bowel symptoms in female patients with irritable bowel syndrome: a double-blind placebo-controlled study. Aliment Pharmacol Ther 22(10):927-934. doi:10. 1111/j.1365-2036.2005.02673.x

117. de Zanette SA, Vercelino R, Laste G, Rozisky JR, Schwertner A, Machado CB, Xavier F, de Souza ICC, Deitos A, Torres ILS, Caumo W (2014) Melatonin analgesia is associated with improvement of the descending endogenous pain-modulating system in fibromyalgia: a phase II, randomized, doubledummy, controlled trial. BMC Pharmacol Toxicol 15(1):1-14. doi:10.1186/ 2050-6511-15-40

118. Andersen LP, Gogenur I, Rosenberg J, Reiter RJ (2016) The safety of melatonin in humans. Clin Drug Investig 36(3):169-175. doi:10.1007/s40261015-0368-5

119. Peres MF, Masruha MR, Zukerman E, Moreira-Filho CA, Cavalheiro EA (2006) Potential therapeutic use of melatonin in migraine and other headache disorders. Expert Opin Investig Drugs 15(4):367-375. doi:10.1517/13543784. 15.4.367

120. Bougea A, Spantideas N, Lyras V, Avramidis T, Thomaidis T (2016) Melatonin $4 \mathrm{mg}$ as prophylactic therapy for primary headaches: a pilot study. Funct Neurol 31(1):33-37

121. Members: IHSCTS, Tfelt-Hansen P, Pascual J, Ramadan N, Dahlöf C, D'Amico D, Diener H-C, Hansen JM, Lanteri-Minet M, Loder E, McCrory D, Plancade S, Schwedt T (2012) Guidelines for controlled trials of drugs in migraine: third edition. A guide for investigators. Cephalalgia 32(1):6-38. doi:10.1177/ 0333102411417901

122. Peres MF, Zukerman E, da Cunha TF, Moreira FR, Cipolla-Neto J (2004) Melatonin, $3 \mathrm{mg}$, is effective for migraine prevention. Neurology 63(4):757

123. Miano S, Parisi P, Pelliccia A, Luchetti A, Paolino MC, Villa MP (2008) Melatonin to prevent migraine or tension-type headache in children. Neurol Sci 29(4):285-287

124. Alstadhaug KB, Odeh F, Salvesen R, Bekkelund SI (2010) Prophylaxis of migraine with melatonin: a randomized controlled trial. Neurology 75(17): 1527-1532. doi:10.1212/WNL.0b013e3181f9618c

125. Fallah R, Shoroki FF, Ferdosian F (2015) Safety and efficacy of melatonin in pediatric migraine prophylaxis. Curr Drug Saf 10(2):132-135

126. Jones RS (1982) Tryptamine: a neuromodulator or neurotransmitter in mammalian brain? Prog Neurobiol 19(1-2):117-139

127. Mousseau DD (1993) Tryptamine: a metabolite of tryptophan implicated in various neuropsychiatric disorders. Metab Brain Dis 8(1):1-44. doi:10.1007/ bf01000528

128. D'Andrea G, D'Amico D, Bussone G, Bolner A, Aguggia M, Saracco MG, Galloni E, De Riva V, D'Arrigo A, Colavito D, Leon A, Perini F (2014) Tryptamine levels are low in plasma of chronic migraine and chronic tension-type headache. Neurol Sci 35(12):1941-1945. doi:10.1007/s10072-014-1867-5

129. D'Andrea G, Cevoli S, Colavito D, Leon A (2015) Biochemistry of primary headaches: role of tyrosine and tryptophan metabolism. Neurol Sci 36(1): 17-22. doi:10.1007/s10072-015-2131-3

130. D'Andrea G, D'Amico D, Bussone G, Bolner A, Aguggia M, Saracco MG, Galloni E, De Riva V, Colavito D, Leon A, Rosteghin V, Perini F (2013) The role of tyrosine metabolism in the pathogenesis of chronic migraine. Cephalalgia 33(11):932-937. doi:10.1177/0333102413480755

131. D'Andrea G, Leone M, Bussone G, Fiore PD, Bolner A, Aguggia M, Saracco MG, Perini F, Giordano G, Gucciardi A, Leon A (2016) Abnormal tyrosine metabolism in chronic cluster headache. Cephalalgia. doi:10.1177/ 0333102416640502

132. Stahl SM (1977) The human platelet. A diagnostic and research tool for the study of biogenic amines in psychiatric and neurologic disorders. Arch Gen Psychiatry 34(5):509-516

133. Gerring Z, Rodriguez-Acevedo AJ, Powell JE, Griffiths LR, Montgomery GW, Nyholt DR (2016) Blood gene expression studies in migraine: potential and caveats. Cephalalgia 36(7):669-678. doi:10.1177/0333102416628463

134. Saulin A, Savli M, Lanzenberger R (2012) Serotonin and molecular neuroimaging in humans using PET. Amino Acids 42(6):2039-2057

135. Paterson LM, Kornum BR, Nutt DJ, Pike WW, Knudsen GM (2013) 5-HT radioligands for human brain imaging with PET and SPECT. Med Res Rev 33(1):54-111. doi:10.1002/med.20245

136. Fumita M, Robert BI In vivo molecular imaging: ligand development and research applications. In: in Neuropsychopharmacology: The Fifth Generation of Progress, 2000. Citeseer,
137. Willeit M, Praschak-Rieder N (2010) Imaging the effects of genetic polymorphisms on radioligand binding in the living human brain: a review on genetic neuroreceptor imaging of monoaminergic systems in psychiatry. Neuroimage 53(3):878-892. doi:10.1016/j.neuroimage.2010.04.030

138. Nishizawa S, Leyton M, Okazawa H, Benkelfat C, Mzengeza S, Diksic M (1998) Validation of a less-invasive method for measurement of serotonin synthesis rate with alpha-[11C]methyl-tryptophan. J Cereb Blood Flow Metab 18(10): 1121-1129. doi:10.1097/00004647-199810000-00009

139. Muzik O, Chugani DC, Chakraborty P, Mangner T, Chugani HT (1997) Analysis of [C-11]alpha-methyl-tryptophan kinetics for the estimation of serotonin synthesis rate in vivo. J Cereb Blood Flow Metab 17(6):659-669. doi:10.1097/00004647-199706000-00007

140. Chugani DC, Niimura K, Chaturvedi S, Muzik O, Fakhouri M, Lee ML, Chugani HT (1999) Increased brain serotonin synthesis in migraine. Neurology 53(7): 1473-1479

141. Lothe A, Merlet I, Demarquay G, Costes N, Ryvlin P, Mauguiere F (2008) Interictal brain 5-HT1A receptors binding in migraine without aura: a $18 \mathrm{~F}$ MPPF-PET study. Cephalalgia 28(12):1282-1291. doi:10.1111/j.1468-2982. 2008.01677.x

142. Schuh-Hofer $S$, Richter M, Geworski L, Villringer A, Israel H, Wenzel R, Munz DL, Arnold G (2007) Increased serotonin transporter availability in the brainstem of migraineurs. J Neurol 254(6):789-796. doi:10.1007/s00415-006-0444-0

143. Sakai Y, Dobson C, Diksic M, Aube M, Hamel E (2008) Sumatriptan normalizes the migraine attack-related increase in brain serotonin synthesis. Neurology 70(6):431-439. doi:10.1212/01.wnl.0000299095.65331.6f

144. Dobson CF, Tohyama Y, Diksic M, Hamel E (2004) Effects of acute or chronic administration of anti-migraine drugs sumatriptan and zolmitriptan on serotonin synthesis in the rat brain. Cephalalgia 24(1):2-11

145. Sakai Y, Nishikawa M, Diksic M, Aube M (2014) alpha-[11C] methyl-L tryptophan-PET as a surrogate for interictal cerebral serotonin synthesis in migraine without aura. Cephalalgia 34(3):165-173. doi:10.1177/ 0333102413506126

146. Park E, Hwang YM, Chu MK, Jung KY (2016) Increased brainstem serotonergic transporter availability in adult migraineurs: an [(18)F]FP-CIT PET imaging pilot study. Nucl med mol imaging 50(1):70-75. doi:10.1007/ s13139-015-0373-x

147. Harrington MG (2006) Cerebrospinal fluid biomarkers in primary headache disorders. Headache 46(7):1075-1087. doi:10.1111/j.1526-4610.2006.00501.x

148. Barrie M, Jowett A (1967) A pharmacological investigation of cerebro-spinal fluid from patients with migraine. Brain 90(4):785-794

149. Kangasni P, Sonninen V, Rinne UK (1972) Excretion of free and conjugated 5-HIAA and VMA in urine and concentration of 5-HIAA and HVA in CSF during migraine attacks and free intervals. Headache 12(2):62-65. doi:10. 1111/j.1526-4610.1972.hed1202062.x

150. Fischer HP, Eich W, Russell IJ (1998) A possible role for saliva as a diagnostic fluid in patients with chronic pain. Semin Arthritis Rheum 27(6):348-359. doi:10.1016/S0049-0172(98)80014-0

151. Nicolodi M, Del Bianco E (1990) Sensory neuropeptides (substance P, calcitonin gene-related peptide) and vasoactive intestinal polypeptide in human saliva: their pattern in migraine and cluster headache. Cephalalgia 10(1):39-50

152. Holsinger FC, Bui D (2007) Anatomy, function, and evaluation of the salivary glands. In: Myers E, Ferris R (eds) Salivary gland disorders. Springer, Berlin, pp 1-16. doi:10.1007/978-3-540-47072-4_1

153. Cady RK, Vause CV, Ho TW, Bigal ME, Durham PL (2009) Elevated saliva calcitonin gene-related peptide levels during acute migraine predict therapeutic response to rizatriptan. Headache 49(9):1258-1266. doi:10.1111/j. 1526-4610.2009.01523.x

154. Bellamy JL, Cady RK, Durham PL (2006) Salivary levels of CGRP and VIP in rhinosinusitis and migraine patients. Headache 46(1):24-33. doi:10.1111/j. 1526-4610.2006.00294.x

155. Marukawa H, Shimomura T, Takahashi K (1996) Salivary substance P, 5hydroxytryptamine, and gamma-aminobutyric acid levels in migraine and tension-type headache. Headache 36(2):100-104

156. Tajti J, Szok D, Majlath Z, Tuka B, Csati A, Vecsei L (2015) Migraine and neuropeptides. Neuropeptides 52:19-30. doi:10.1016/j.npep.2015.03.006

157. Iantorno M, Campia U, Di Daniele N, Nistico S, Forleo GB, Cardillo C, Tesauro M (2014) Obesity, inflammation and endothelial dysfunction. J Biol Regul Homeost Agents 28(2):169-176

158. Murinova N, Krashin DL, Lucas S (2014) Vascular risk in migraineurs: interaction of endothelial and cortical excitability factors. Headache 54(3): 583-590. doi:10.1111/head.12304 
159. Miller Alyson A, Budzyn K, Sobey Christopher G (2010) Vascular dysfunction in cerebrovascular disease: mechanisms and therapeutic intervention. Clin Sci 119(1):1-17. doi:10.1042/cs20090649

160. Lenart N, Brough D, Denes A (2016) Inflammasomes link vascular disease with neuroinflammation and brain disorders. J Cereb Blood Flow Metab. doi:10.1177/0271678×16662043

161. Bernatova I (2014) Endothelial dysfunction in experimental models of arterial hypertension: cause or consequence? Biomed Res Int 2014:14. doi: 10.1155/2014/598271

162. Dalkara T, Nozari A, Moskowitz MA (2010) Migraine aura pathophysiology: the role of blood vessels and microembolisation. Lancet Neurol 9(3):309317. doi:10.1016/S1474-4422(09)70358-8

163. Kurth T (2013) Migraine a marker of vascular health? Cephalalgia 33(4):226227. doi:10.1177/0333102412472074

164. Pierangeli G, Giannini G, Favoni V, Sambati L, Cevoli S, Cortelli P (2012) Migraine and cardiovascular diseases. Neurol Sci 33(Suppl 1):S47-50. doi:10. 1007/s10072-012-1040-y

165. Jernej B, Vladic A, Cicin-Sain L, Hranilovic D, Banovic M, Balija M, Bilic E, Sucic Z, Vukadin S, Grgicevic D (2002) Platelet serotonin measures in migraine. Headache 42(7):588-595

166. Gill RK, Pant N, Saksena S, Singla A, Nazir TM, Vohwinkel L, Turner JR, Goldstein J, Alrefai WA, Dudeja PK (2008) Function, expression, and characterization of the serotonin transporter in the native human intestine. Am J Physiol Gastrointest Liver Physiol 294(1):G254-G262. doi:10.1152/ajpgi. 00354.2007

167. Van Hemert S, Breedveld A, Rovers J, Vermeiden J, Witteman B, Smits M, de Roos N (2014) Migraine associated with gastrointestinal disorders: review of the literature and clinical implications. Frontiers in Neurology 5. doi:10.3389/ fneur.2014.00241

168. Mawe GM, Hoffman JM (2013) Serotonin signaling in the gastrointestinal tract: functions, dysfunctions, and therapeutic targets. Nat Rev Gastroenterol Hepatol 10(8):473-486. doi:10.1038/nrgastro.2013.105

169. Lesch KP, Wolozin BL, Murphy DL, Reiderer P (1993) Primary structure of the human platelet serotonin uptake site: identity with the brain serotonin transporter. J Neurochem 60(6):2319-2322

170. Rose'Meyer R (2013) A review of the serotonin transporter and prenatal cortisol in the development of autism spectrum disorders. Molecular Autism 4:37-37. doi:10.1186/2040-2392-4-37

171. Bengel D, Murphy DL, Andrews AM, Wichems CH, Feltner D, Heils A, Mossner R, Westphal H, Lesch KP (1998) Altered brain serotonin homeostasis and locomotor insensitivity to 3, 4methylenedioxymethamphetamine ("Ecstasy") in serotonin transporterdeficient mice. Mol Pharmacol 53(4):649-655

172. Kim DK, Tolliver TJ, Huang SJ, Martin BJ, Andrews AM, Wichems C, Holmes A, Lesch KP, Murphy DL (2005) Altered serotonin synthesis, turnover and dynamic regulation in multiple brain regions of mice lacking the serotonin transporter. Neuropharmacology 49(6):798-810. doi:10.1016/j.neuropharm. 2005.08.010

173. Altamura C, Dell'Acqua ML, Moessner R, Murphy DL, Lesch KP, Persico AM (2007) Altered neocortical cell density and layer thickness in serotonin transporter knockout mice: a quantitation study. Cereb Cortex 17(6):13941401. doi:10.1093/cercor/bhl051

174. Nietzer SL, Bonn M, Jansen F, Heiming RS, Lewejohann L, Sachser N, Asan ES, Lesch KP, Schmitt AG (2011) Serotonin transporter knockout and repeated social defeat stress: Impact on neuronal morphology and plasticity in limbic brain areas. Behav Brain Res 220(1):42-54, http://dx.doi.org/10. 1016/j.bbr.2011.01.011

175. Hanington E (1989) Migraine - the platelet hypothesis after 10 years. Biomed Pharmacother 43(10):719-726. doi:10.1016/0753-3322(89)90160-

176. Danese E, Montagnana M, Lippi G (2014) Platelets and migraine. Thromb Res 134(1):17-22. doi:10.1016/j.thromres.2014.03.055

177. Horvath GA, Selby K, Poskitt K, Hyland K, Waters PJ, Coulter-Mackie M, Stockler-Ipsiroglu SG (2011) Hemiplegic migraine, seizures, progressive spastic paraparesis, mood disorder, and coma in siblings with low systemic serotonin. Cephalalgia 31(15):1580-1586. doi:10.1177/0333102411420584

178. D'Andrea G, Hasselmark L, Alecci M, Cananzi A, Perini F, Welch KM (1994) Platelet secretion from dense and alpha-granules in vitro in migraine with or without aura. J Neurol Neurosurg Psychiatry 57(5):557-561

179. Kovacs K, Herman F, Filep J, Jelencsik I, Magyar K, Csanda E (1990) Platelet aggregation of migraineurs during and between attacks. Cephalalgia 10(4): $161-165$
180. Goubau C, Buyse GM, Van Geet C, Freson K (2014) The contribution of platelet studies to the understanding of disease mechanisms in complex and monogenetic neurological disorders. Dev Med Child Neurol 56(8):724731. doi:10.1111/dmen.12421

181. Tietjen GE, Khubchandani I (2009) Platelet dysfunction and stroke in the female migraineur. Curr Pain Headache Rep 13(5):386-391

182. Franco D, Franco T, Schettino AM, Filho JM, Vendramin FS (2012) Protocol for obtaining platelet-rich plasma (PRP), platelet-poor plasma (PPP), and thrombin for autologous use. Aesthetic Plast Surg 36(5):1254-1259. doi:10. 1007/s00266-012-9957-3

183. Brand T, Anderson GM (2011) The measurement of platelet-poor plasma serotonin: a systematic review of prior reports and recommendations for improved analysis. Clin Chem 57(10):1376-1386. doi:10.1373/clinchem.2011. 163824

184. Dvilansky A, Rishpon S, Nathan I, Zolotow Z, Korczyn AD (1976) Release of Platelet 5-Hydroxytryptamine by Plasma Taken from Patients during and between Migraine Attacks. Pain 2(3):315-318. doi:10.1016/03043959(76)90009-9

185. Ferrari MD, Odink J, Tapparelli C, Van Kempen GM, Pennings EJ, Bruyn GW (1989) Serotonin metabolism in migraine. Neurology 39(9):1239-1242

186. Milovanovic DD, Majkic-Sing N, Mirkovic D, Pavlovic J (1999) Plasma and urinary serotonin and 5-hydroxyindol-3-acetic acid in adults with migraine and tension-type headache. Adv Exp Med Biol 467:191-197

187. Curran DA, Hinterberger H, Lance JW (1965) Total plasma serotonin, 5hydroxyindoleacetic acid and p-hydroxy-m-methoxymandelic acid excretion in normal and migrainous subjects. Brain 88(5):997-1010

188. Rydzewski W (1976) Serotonin (5HT) in migraine: levels in whole blood in and between attacks. Headache 16(1):16-19

189. Nagata E, Shibata M, Hamada J, Shimizu T, Katoh Y, Gotoh K, Suzuki N (2006) Plasma 5-hydroxytryptamine (5-HT) in migraine during an attack-free period. Headache 46(4):592-596. doi:10.1111/j.1526-4610.2006.00408.x

190. Deanovic Z, Iskric S, Dupelj M (1975) Fluctuation of 5-hydroxy-indole compounds in urine of migrainous patients. Biomed Express 23(9):346-349

191. Bousser MG, Elghozi JL, Laude D, Soisson T (1986) Urinary 5-HIAA in migraine - evidence of lowered excretion in young adult females. Cephalalgia 6(4):205-209. doi:10.1046/j.1468-2982.1986.0604205.x

192. Curzon G, Theaker P, Phillips B (1966) Excretion of 5-hydroxyindolyl acetic acid (5HIAA) in migraine. J Neurol Neurosurg Psychiatry 29(1):85-90. doi:10. 1136/jnnp.29.1.85

193. Headache (1962) Ad Hoc committe on classification of headache. JAMA 179:717

194. Headache (1970) World federation of neurology research group on migraine and headache. Definition of migraine. Background to migraine, Cochrane AL. Heineman, London

195. IHS (1988) Classification and diagnostic criteria for the headache disorders, cranial neuralgias and facial pain. Cephalalgia 8:1-96

196. Peterlin BL, Rapoport AM (2007) Clinical pharmacology of the serotonin receptor agonist, zolmitriptan. Expert Opin Drug Metab Toxicol 3(6):899911. doi:10.1517/17425255.3.6.899

197. Crook M (1981) Migraine: a biochemical headache? Biochem Soc Trans 9(4): 351-357

198. Anthony M, Lance JW (1989) Plasma serotonin in patients with chronic tension headaches. J Neurol Neurosurg Psychiatry 52(2):182-184

199. Risch SC, Nemeroff CB (1992) Neurochemical alterations of serotonergic neuronal systems in depression. J Clin Psychiatry 53(Suppl):3-7

200. Mawe GM, Coates MD, Moses PL (2006) Review article: intestinal serotonin signalling in irritable bowel syndrome. Aliment Pharmacol Ther 23(8):10671076. doi:10.1111/j.1365-2036.2006.02858.x

201. Jackson JL, Shimeall W, Sessums L, Dezee KJ, Becher D, Diemer M, Berbano E, O'Malley PG (2010) Tricyclic antidepressants and headaches: systematic review and meta-analysis. BMJ 341:c5222. doi:10.1136/bmj.c5222

202. Supornsilpchai W, Sanguanrangsirikul S, Maneesri S, Srikiatkhachorn A (2006) Serotonin depletion, cortical spreading depression, and trigeminal nociception. Headache 46(1):34-39. doi:10.1111/j.1526-4610.2006.00310.x

203. Maneesri S, Supornsilpchai W, Saengjaroentham C, Pleumsamran J, Srikiatkhachorn A (2010) Effect of serotonin depletion on cortical spreading depression evoked cerebrovascular changes. Asian Biomed 4(5):731-738

204. le Grand SM, Supornsilpchai W, Saengjaroentham C, Srikiatkhachorn A (2011) Serotonin depletion leads to cortical hyperexcitability and trigeminal nociceptive facilitation via the nitric oxide pathway. Headache 51(7):11521160. doi:10.1111/j.1526-4610.2011.01931.x 
205. Dumas M-E, Davidovic L (2013) Metabolic phenotyping and systems biology approaches to understanding neurological disorders. F1000Prime Reports 5:18. doi:10.12703/P5-18

206. Wishart DS, Tzur D, Knox C, Eisner R, Guo AC, Young N, Cheng D, Jewell K, Arndt D, Sawhney S, Fung C, Nikolai L, Lewis M, Coutouly MA, Forsythe I, Tang P, Shrivastava S, Jeroncic K, Stothard P, Amegbey G, Block D, Hau DD, Wagner J, Miniaci J, Clements M, Gebremedhin M, Guo N, Zhang Y, Duggan GE, Macinnis GD, Weljie AM, Dowlatabadi R, Bamforth F, Clive D, Greiner R, Li L, Marrie T, Sykes BD, Vogel HJ, Querengesser L (2007) HMDB: the human metabolome database. Nucleic Acids Res 35(Database issue):D521-526. doi: 10.1093/nar/gkl923

207. Shyti R, Kohler I, Schoenmaker B, Derks RJ, Ferrari MD, Tolner EA, Mayboroda OA, van den Maagdenberg AM (2015) Plasma metabolic profiling after cortical spreading depression in a transgenic mouse model of hemiplegic migraine by capillary electrophoresis-mass spectrometry. Mol Biosyst 11(5): 1462-1471. doi:10.1039/c5mb00049a

208. Bouatra S, Aziat F, Mandal R, Guo AC, Wilson MR, Knox C, Bjorndahl TC, Krishnamurthy R, Saleem F, Liu P, Dame ZT, Poelzer J, Huynh J, Yallou FS, Psychogios N, Dong E, Bogumil R, Roehring C, Wishart DS (2013) The human urine metabolome. PLoS ONE 8(9):e73076. doi:10.1371/journal.pone.0073076

209. Psychogios N, Hau DD, Peng J, Guo AC, Mandal R, Bouatra S, Sinelnikov I, Krishnamurthy R, Eisner R, Gautam B, Young N, Xia J, Knox C, Dong E, Huang P, Hollander Z, Pedersen TL, Smith SR, Bamforth F, Greiner R, McManus B, Newman JW, Goodfriend T, Wishart DS (2011) The human serum metabolome. PLOS ONE 6(2):e16957. doi:10.1371/journal.pone.0016957

210. Dalsgaard-Nielsen T, Genefke IK (1974) Serotonin (5-Hydroxytryptamine) release and uptake in platelets from healthy persons and migrainous patients in attack-free intervals. Headache: J Head Face Pain 14(1):26-32 doi:10.1111/j.1526-4610.1974.hed1401026.x

211. Kalendovsky Z, Austin JH (1975) Complicated migraine its association with increased platelet aggregability and abnormal plasma coagulation-factors. Headache 15(1):18-35. doi:10.1111/j.1526-4610.1975.hed1501018.x

212. Muck-Seler D, Deanovic Z, Dupelj M (1979) Platelet serotonin (5-HT) and 5HT releasing factor in plasma of migrainous patients. Headache 19(1):14-17

213. Rolf LH, Wiele G, Brune GG (1981) 5-Hydroxytryptamine in platelets of patients with muscle contraction headache. Headache 21(1):10-11

214. Carroll JD, Coppen A, Swade CC, Wood KM (1982) Blood platelet 5hydroxytryptamine accumulation and migraine. Adv Neurol 33:233-235

215. Oxman TE, Hitzemann RJ, Smith R (1982) Platelet membrane lipid composition and the frequency of migraine. Headache 22(6):261-267

216. Launay JM, Pradalier A, Dreux C, Dry J (1982) Platelet serotonin uptake and migraine. Cephalalgia 2(2):57-59. doi:10.1046/j.1468-2982.1982.0202057.x

217. Pradalier A, Launay JM, Dry J, Dreux C (1983) Role of platelet serotonin in common migraine - concentrations and uptake. Presse Med 12(37):2311-2314

218. Kruglak L, Nathan I, Korczyn AD, Zolotov Z, Berginer V, Dvilansky A (1984) Platelet aggregability, disaggregability and serotonin uptake in migraine. Cephalalgia 4(4):221-225

219. Lechner H, Ott E, Fazekas F, Pilger E (1985) Evidence of enhanced platelet aggregation and platelet sensitivity in migraine patients. Cephalalgia 5(Suppl 2):89-91

220. Lingjaerde O, Monstad P (1986) The uptake, storage, and efflux of serotonin in platelets from migraine patients. Cephalalgia 6(3):135-139

221. Shukla R, Shanker K, Nag D, Verma M, Bhargava KP (1987) Serotonin in tension headache. J Neurol Neurosurg Psychiatry 50(12):1682-1684. doi:10 1136/jnnp.50.12.1682

222. Kozubski W, Walkowiak B, Cierniewski CS, Prusinski A (1987) Platelet fibrinogen receptors in migraine patients. Headache 27(8):431-434

223. Joseph R, Welch KM, Grunfeld S, Oster SB, D'Andrea G (1988) Cytosolic ionized calcium homeostasis in platelets: an abnormal sensitivity to PAFactivation in migraine. Headache 28(6):396-402

224. D'Andrea G, Welch KM, Grunfeld S, Joseph R, Nagel-Leiby S (1989) Platelet norepinephrine and serotonin balance in migraine. Headache 29(10):657-659

225. D'Andrea G, Welch KM, Riddle JM, Grunfeld S, Joseph R (1989) Platelet serotonin metabolism and ultrastructure in migraine. Arch Neurol 46(11): 1187-1189

226. Herman F, Magyar K, Kovacs K, Filep J (1989) Decreased sensitivity of platelets to platelet-activating factor in migraine patients during the headache-free interval. Thromb Haemost 62(2):818

227. Takeshima T, Takao Y, Urakami K, Nishikawa S, Takahashi K (1989) Muscle contraction headache and migraine. Platelet activation and plasma norepinephrine during the cold pressor test. Cephalalgia 9(1):7-13
228. Riddle JM, D'Andrea G, Welch KM, Joseph R, McElroy HH, Grunfeld S, Christopherson TG (1989) Platelet activation and analysis of organelles in migraineurs. Headache 29(1):28-33

229. Govitrapong P, Limthavon C, Srikiatkhachorn A (1992) 5-HT2 serotonin receptor on blood platelet of migraine patients. Headache 32(10):480-484

230. Cotrim MD, Ribeiro CAF, Demacedo TDA (1993) Changes in platelet membrane fluidity of migraine patients. Cephalalgia 13(2):99-101. doi:10. 1046/j.1468-2982.1993.1302099.x

231. Jensen R, Hindberg I (1994) Plasma serotonin increase during episodes of tension-type headache. Cephalalgia 14(3):219-222, discussion 181

232. Kitano A, Shimomura T, Takeshima T, Takahashi K (1994) Increased 11dehydrothromboxane B2 in migraine: platelet hyperfunction in patients with migraine during headache-free period. Headache 34(9):515-518

233. Jarman J, Pattichis K, Peatfield R, Glover V, Sandler M (1996) Red wineinduced release of [14C]5-hydroxytryptamine from platelets of migraine patients and controls. Cephalalgia 16(1):41-43

234. Fioroni L, Andrea GD, Alecci M, Cananzi A, Facchinetti F (1996) Platelet serotonin pathway in menstrual migraine. Cephalalgia 16(6):427-430

235. Srikiatkhachorn A, Anthony M (1996) Platelet serotonin in patients with analgesic-induced headache. Cephalalgia 16(6):423-426

236. Pukhal'skaya TG, Kolosova OA, Men'shikov MY (1998) Serotonin-induced platelet aggregation and release of $3 \mathrm{H}$-serotonin in patients with migraine. Bull Exp Biol Med 126(2):780-782. doi:10.1007/BF02446908

237. Oishi M, Mochizuki Y (1998) beta-thromboglobulin and 11dehydrothromboxane B-2 in tension-type headache. Headache 38(9):676678. doi:10.1046/j.1526-4610.1998.3809676.x

238. Srikiatkhachorn A, Maneesri S, Govitrapong P, Kasantikul V (1998) Derangement of serotonin system in migrainous patients with analgesic abuse headache: clues from platelets. Headache 38(1):43-49

239. Sarchielli P, Alberti A, Coppola F, Baldi A, Gallai B, Floridi A, Floridi A, Capocchi G, Gallai V (2004) Platelet-activating factor (PAF) in internal jugular venous blood of migraine without aura patients assessed during migraine attacks. Cephalalgia 24(8):623-630. doi:10.1111/j.1468-2982.2003.00717.x

240. Yucel Y, Tanriverdi H, Arikanoglu A, Varol S, Kaplan I, Akil E, Celepkolu T, Uzar E (2014) Increased fibrinogen, D-dimer and galectin-3 levels in patients with migraine. Neurol Sci 35(4):545-549. doi:10.1007/s10072-013-1542-2

241. Couch JR, Hassanein RS (1976) Platelet aggregability in migraine and relation of aggregability to clinical aspects of migraine. Neurology 26(4):348-348

242. Couch JR, Hassanein RS (1977) Platelet aggregability in migraine. Neurology 27(9):843-848

243. Deshmukh SV, Meyer JS (1977) Cyclic changes in platelet dynamics and the pathogenesis and prophylaxis of migraine. Headache 17(3):101-108

244. Manotti C, Manzoni GC, Moretti G, Poti R, Tagliaferri A (1983) Study of platelet function in patients with migraine. Haematologica 68(6):775-781

245. Waldenlind E, Ross SB, Saaf J, Ekbom K, Wetterberg L (1985) Concentration and uptake of 5-hydroxytryptamine in platelets from cluster headache and migraine patients. Cephalalgia 5(1):45-54

246. Buttinelli C, Lazzaro MP, Lenzi GL, Paolucci S, Prencipe M (1985) Correlation between migraine and circulating platelet aggregates. Cephalalgia 5(Suppl 2):87-88

247. Walkowiak B, Kozubski W, Pawlowska Z, Prusinski A, Cierniewski CS (1989) Expression of fibrinogen receptors in platelets of migraine patientscorrelation with platelet GPIlb content and plasma cholesterol. Thromb Haemost 61(3):419-422

248. Joseph R, Welch KM, D'Andrea G (1989) Serotonergic hypofunction in migraine: a synthesis of evidence based on platelet dense body dysfunction. Cephalalgia 9(4):293-299

249. Ribeiro CA, Cotrim MD, Morgadinho MT, Ramos MI, Santos ES, de Macedo TR (1990) Migraine, serum serotonin and platelet 5-HT2 receptors. Cephalalgia 10(5):213-219

250. Jha S, Varma M, Garg R, Kar AM (1992) Platelet aggregation in migraine. J Assoc Physicians India 40(3):153-154

251. Leira R, Castillo J, Martinez F, Prieto JM, Noya M (1993) Platelet-rich plasma serotonin levels in tension-type headache and depression. Cephalalgia 13(5):346-348. doi:10.1046/j.1468-2982.1993.1305346.x

252. D'Andrea G, Hasselmark L, Cananzi AR, Alecci M, Perini F, Zamberlan F, Welch KM (1995) Metabolism and menstrual cycle rhythmicity of serotonin in primary headaches. Headache 35(4):216-221

253. Allais G, Facco G, Ciochetto D, De Lorenzo C, Fiore M, Benedetto C (1997) Patterns of platelet aggregation in menstrual migraine. Cephalalgia 17(Suppl 20):39-41 
254. Zeller JA, Lindner V, Frahm K, Baron R, Deuschl G (2005) Platelet activation and platelet-leucocyte interaction in patients with migraine. Subtype differences and influence of triptans. Cephalalgia 25(7):536-541. doi:10.1111/ j.1468-2982.2005.00916.x

255. Taffi R, Vignini A, Lanciotti C, Luconi R, Nanetti L, Mazzanti L, Provinciali L, Silvestrini M, Bartolini M (2005) Platelet membrane fluidity and peroxynitrite levels in migraine patients during headache-free periods. Cephalalgia 25(5): 353-358. doi:10.1111/j.1468-2982.2004.00863.x

\section{Submit your manuscript to a SpringerOpen ${ }^{\circ}$ journal and benefit from:}

- Convenient online submission

- Rigorous peer review

- Immediate publication on acceptance

- Open access: articles freely available online

- High visibility within the field

- Retaining the copyright to your article

Submit your next manuscript at $\boldsymbol{s p r i n g e r o p e n . c o m ~}$ 